\title{
A Champion of Host Defense: A Generic Large-Scale Cause for Platelet Dysfunction and Depletion in Infection
}

\author{
Martin J. Page, BSc (Hons) ${ }^{1}$ Etheresia Pretorius, $\mathrm{PhD}^{1}{ }^{\circledR}$ \\ ${ }^{1}$ Department of Physiological Sciences, Stellenbosch University, \\ Stellenbosch, South Africa \\ Semin Thromb Hemost 2020;46:302-319. \\ Address for correspondence Etheresia Pretorius, PhD, Department of \\ Physiological Sciences, Faculty of Science, Stellenbosch University, \\ Private Bag X1 Matieland, Stellenbosch, 7602, South Africa \\ (e-mail: resiap@sun.ac.za).
}

\begin{abstract}
Thrombocytopenia is commonly associated with sepsis and infections, which in turn are characterized by a profound immune reaction to the invading pathogen. Platelets are one of the cellular entities that exert considerable immune, antibacterial, and antiviral actions, and are therefore active participants in the host response. Platelets are sensitive to surrounding inflammatory stimuli and contribute to the immune response by multiple mechanisms, including endowing the endothelium with a proinflammatory phenotype, enhancing and amplifying leukocyte recruitment and inflammation, promoting the effector functions of immune cells, and ensuring an optimal adaptive immune response. During infection, pathogens and their products influence the platelet response and can even be toxic. However, platelets are able to sense and engage bacteria and viruses to assist in their removal and destruction. Platelets greatly contribute to host defense by multiple mechanisms, including forming immune complexes and aggregates, shedding their granular content, and internalizing pathogens and subsequently being marked for removal. These processes, and the nature of platelet function in general, cause the platelet to be irreversibly consumed in

Keywords

- platelets

- virus

- bacteria

- thrombocytopenia

- immune response the execution of its duty. An exaggerated systemic inflammatory response to infection can drive platelet dysfunction, where platelets are inappropriately activated and face immunological destruction. While thrombocytopenia may arise by condition-specific mechanisms that cause an imbalance between platelet production and removal, this review evaluates a generic large-scale mechanism for platelet depletion as a repercussion of its involvement at the nexus of responses to infection.
\end{abstract}

Infections, both bacterial and viral, are associated with a profound immune response to the infecting pathogen. Platelets are important contributors to the multifaceted response to infection, where they have the ability to modulate various immune cells. Platelets engage the immune system through direct cell-to-cell interaction and through the release of various soluble mediators. ${ }^{1-5}$ Furthermore, platelets participate in the interaction between pathogens and host defense. ${ }^{6-12}$ In the absence of platelets, bacteremia, tissue damage, and
Issue Theme Acquired Platelet Dysfunction-Laboratory and

Clinical Implications; Guest

Editors: Anne-Mette Hvas, MD, PhD,

Julie Brogaard Larsen, MD, PhD, and Tel: +1(212) 760-0888.

Leonardo Pasalic, MBBS, PhD. mortality are greatly enhanced. ${ }^{13-15}$ Similarly, thrombocytopenia is associated with a dysregulated host response and worse outcomes in sepsis patients. ${ }^{16,17}$ Platelets are also active participants in the host response to viruses, and have been shown to be protective in viral infections. ${ }^{18-20}$

Platelets possess receptors that allow them to survey for danger signals from pathogens (pathogen-associated molecular patterns; PAMPs) and cell damage (damage-associated molecular patterns; DAMPs), and trigger hemostatic and
Copyright $\odot 2020$ by Thieme Medical Publishers, Inc., 333 Seventh Avenue, New York, 
inflammatory responses against bacterial and viral infections. $^{3,21,22}$ During infection, the platelet is activated, mobilized, and actively participates in the resultant hemostatic and inflammatory responses. These signaling processes involve many feedback loops that self-amplify initial activation, ${ }^{23}$ and platelets can manifest dysfunction even in cases where no bacteremia is present. ${ }^{10}$ These processes are irreversible and undoubtedly lead to consumption of the platelet. Activation of platelets leads to their consumption into aggregates with other platelets, leukocytes, and the endothelium. ${ }^{24} \mathrm{Pla}-$ telets with bound antibody are targets of phagocytes, and platelets with a bacterial or viral load are sequestrated and also cleared from the circulation. Further, pathogenic compounds induce apoptosis and cytotoxic effects in platelets. ${ }^{25}$ In this sense, activated platelets and platelets interacting with pathogens have shortened survival spans and experience increased destruction. The outcome for the patient will be a decrease in normal circulating platelets, and if this manifests widely enough it can be measured as thrombocytopenia. ${ }^{3,25}$

Other mechanisms of platelet decline in infection exist and include the formation of autoantibodies against platelet surface proteins, which leads to clearance of immunoglobulin G ( $\operatorname{lgG}$ )coated platelets by the reticuloendothelial system, ${ }^{26,27}$ as well as by impaired platelet production in the bone marrow, 3,6 among others. ${ }^{6}$ However, a general view of platelet destruction is the simple characteristic that their involvement in thrombotic, hemostatic, immune, and host defense responses is irreversible. Even if platelets are positive contributors to the host response against invading pathogens, they can become dysfunctional, especially in the context of an excessive and unbalanced systemic inflammatory response. ${ }^{16,28}$ Indeed, the dysfunctional state of thrombocytopenia is commonly associated with sepsis and infections. ${ }^{3,29-31}$

The focus of the current review is platelets and their role in infection. We will examine the interaction of platelets, their receptors, and secretory product with bacteria and viruses, and discuss how this may contribute to platelet dysfunction and ultimately lead to thrombocytopenia. - Fig. 1 provides the

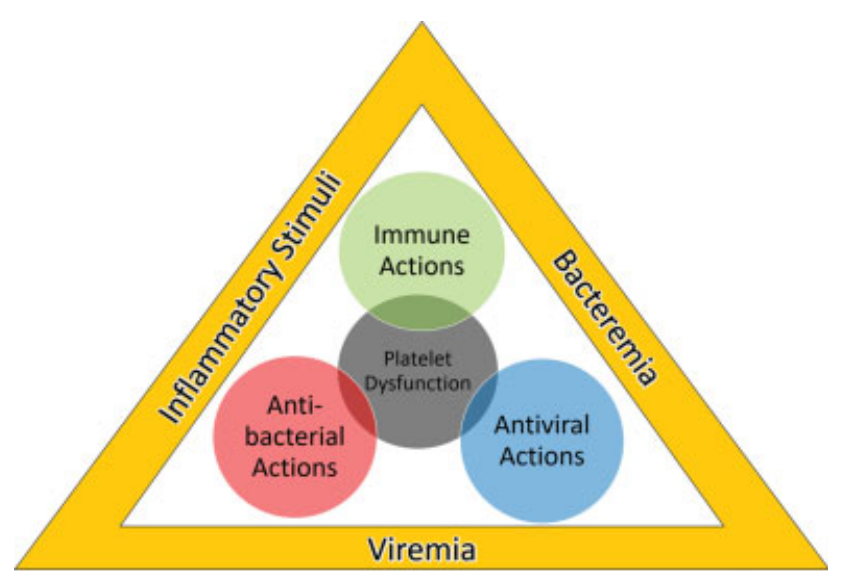

Fig. 1 Layout of the review. During infection, inflammatory stimuli, and the presence of bacteria, viruses and their products mobilize platelets to exert their immune, antibacterial, and antiviral actions. However, these processes can also lead to platelet dysfunction and ultimately depletion. rationale of this review and - Table 1 lists the abbreviations used in this article.

\section{Platelet and the Immune Response to Infections}

A common feature of many infections, both viral and bacterial, is a systemic inflammatory response that involves a dysregulated proinflammatory biomarker presence in the circulation. 3,5,32 These biomarkers may include cytokines (e.g., interleukins [ILs], tumor necrosis factor [TNF]- $\alpha$, and interferons) but also molecules originating from bacteria and viruses themselves (e.g., proteases, ribonucleic acid [RNA], and membrane components like lipopolysaccharide [LPS], lipoteichoic acid [LTA], and viral glycoproteins). The presence of such circulating biomarkers has profound agonistic effects on platelets.

Platelets contribute to the thromboinflammatory response through the plethora of membrane and cytosolic molecules that they express and release, which possess hemostatic, immunomodulatory, and inflammatory activity. ${ }^{1-4}$ Platelets possess receptors that enable pathogen sensing, and which allow platelets to regulate leukocytes and other cells at the site of infection. During platelet activation, degranulation leads to the surface expression of receptors and the release of abundant proinflammatory mediators, which contribute to numerous signaling events. ${ }^{1-5}$ Platelets also adhere and aggregate to other platelets and to endothelial cells, leukocytes, and erythrocytes. ${ }^{5,9,24}$ This response is also characteristic during bacterial and viral infections, and can be induced by pathogens directly. ${ }^{33}$ This section describes the role of platelets in the immune response. See - Fig. 2 for a general overview of platelet receptors and secretory products.

\section{Platelet-Endothelium Interactions: Endowing a Proinflammatory Phenotype}

Endothelial activation markers are raised during infection, and are associated with a thrombotic state. ${ }^{34}$ During activation, platelets can bind to the endothelium. ${ }^{24}$ This especially occurs upon endothelial damage due to trauma or microbial colonization, ${ }^{35}$ as well as in viral infections. ${ }^{36}$ Platelets become activated during the adhesion process, and the inflammatory and mitogenic substances that are released alter the chemotactic, adhesive, and proteolytic properties of endothelial cells. ${ }^{37}$ Platelet adhesion therefore endows the endothelium with a proinflammatory phenotype. ${ }^{24}$ Moreover, platelets that are bound to the endothelium can form a bridging connection with circulating leukocytes. ${ }^{24}$ Overall, these mechanisms amplify and facilitate leukocyte recruitment and enhance inflammation. -Fig. 3 provides an overview of the contact between platelets and cells at the vascular wall to emphasize the involvement of platelets in multiple interactions at the vessel wall.

\section{Platelet-Leukocyte Interactions: Promoting Immune Cell Effector Functions against Pathogens}

Interactions between platelets and leukocytes are important for the regulation of the immune response and for the clearance of infectious agents. By binding and activating leukocytes, platelets promote their effector functions. Coordination of 
304 Platelet Dysfunction and Depletion in Infection Page, Pretorius

Table 1 List of abbreviations

\begin{tabular}{|c|c|c|}
\hline Abbreviation & Full term & Synonyms \\
\hline$\alpha \mathrm{llb} \beta 3$ & & GPIIb/IIIa \\
\hline$\alpha \mathrm{M} \beta 2$ & Macrophage- 1 antigen & CD11b/CD18, CR3; Mac-1 \\
\hline CAMP & Cyclic adenosine monophosphate & \\
\hline CAR receptor & Coxsackievirus and adenovirus receptor & \\
\hline (s)CD40L & (Soluble) CD40 ligand & CD154 \\
\hline cGMP & Cyclic guanosine monophosphate & \\
\hline CR2 & Complement receptor 2 & CD21, C3dR \\
\hline CR3 & Complement receptor 3 & $\alpha M \beta 2$, CD11b/CD18, Mac-1 \\
\hline CR4 & Complement receptor 4 & $\alpha \times \beta 2, C D 11 c / C D 18$ \\
\hline DAMP & Damage-associated molecular pattern & \\
\hline DNA & Deoxyribonucleic acid & \\
\hline Eap & Extracellular adherence protein & \\
\hline Efb & Extracellular fibrinogen binding protein & \\
\hline FcyRlla & Low affinity immunoglobulin gamma Fc region receptor II-a & CD32 \\
\hline GPIb & Glycoprotein Ib & CD42 \\
\hline GPVI & Glycoprotein VI & \\
\hline HIV & Human immunodeficiency virus & \\
\hline HLA-DR & Human leukocyte antigen-DR isotype & \\
\hline HRgpA & Recombinant gingipain R1 protease (high molecular mass form) & \\
\hline $\lg$ & Immunoglobulin & \\
\hline IL & Interleukin & \\
\hline LCMV & Lymphocytic choriomeningitis virus & \\
\hline LPS & Lipopolysaccharide & \\
\hline LTA & Lipoteichoic acid & \\
\hline MyD88 & Myeloid differentiation primary response 88 & \\
\hline NET & Neutrophil extracellular trap & \\
\hline P-selectin & & CD62P, GMP-140, PADGEM \\
\hline PAF & Platelet-activating factor & \\
\hline PAMP & Pathogen-associated molecular pattern & \\
\hline PAR & Protease-activated receptor & \\
\hline PF4 & Platelet factor 4 & CXCL4 \\
\hline PKG & cGMP-dependent protein kinase & \\
\hline PSGL-1 & P-selectin glycoprotein ligand-1 & CD162 \\
\hline RANTES & Regulated on activation, normal T-cell expressed and secreted & CCL5 \\
\hline RgpB & Recombinant gingipain $\mathrm{R} 2$ protease & \\
\hline RNA & Ribonucleic acid & \\
\hline ROS & Reactive oxygen species & \\
\hline SSL & Staphylococcal superantigen-like & \\
\hline TLR & Toll-like receptor & \\
\hline TNF & Tumor necrosis factor & \\
\hline TREM-1(L) & Triggering receptor expressed on myeloid cells 1 (ligand) & CD354 \\
\hline
\end{tabular}




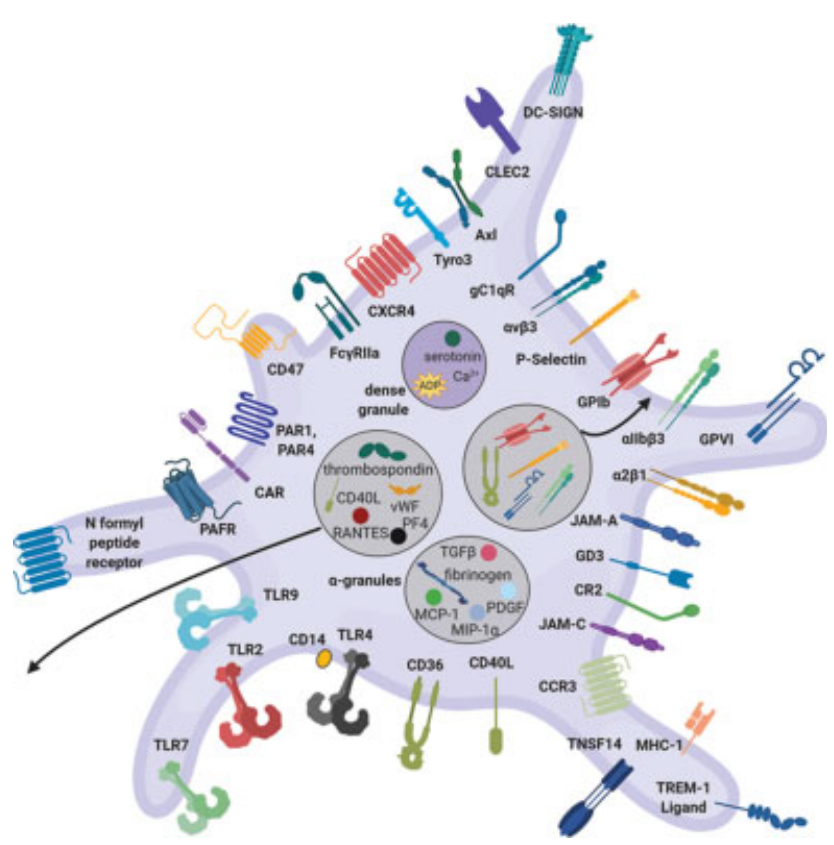

Fig. 2 General platelet structure. Platelets express various receptors that allow them to detect danger signals and engage other cells. Platelets are activated by various agonists that interact with surface receptors. Platelets are also replete with secretory granules that store bioactive molecules, which are released into the circulation or translocate to the surface upon platelet activation. These characteristics allow platelets to communicate and modulate the functions of other cells, and trigger hemostatic, inflammatory, and host defense responses against infections (created with https://biorender.com/). ADP, adenosine diphosphate; CAR, coxsackievirus and adenovirus receptor; CCR/CXCR, chemokine receptor; CLEC, C-type lectin-like receptor; $C R$, complement receptor; DC-SIGN, dendritic cell-specific ICAM-grabbing nonintegrin; FcyRIla, low-affinity immunoglobulin gamma Fc region receptor II-a; gC1Qr, receptor for the globular heads of C1q; JAM, junction adhesion molecule; MCP, monocyte chemoattractant protein; MHC, major histocompatibility complex; MIP, macrophage inflammatory protein; PAFR, platelet-activating factor receptor; PAR, protease-activated receptor; PDGF, platelet-derived growth factor; PF, platelet factor; RANTES, regulated on activation, normal T-cell expressed and secreted; TGF, transforming growth factor; TLR, toll-like receptor; TNSF14, tumor necrosis factor superfamily member 14; TREM, triggering receptor expressed on myeloid cells; vWF, von Willebrand factor.

immune cells by platelets ensures a rapid and targeted host defense response. In a dynamic cross-talk, leukocytes can also release factors that modulate platelet function.

Platelets adhere to phagocytes and deliver signals that enhance the killing of internalized pathogens. Platelets are able to modulate neutrophil responses where they enhance neutrophil phagocytosis in a process involving toll-like receptor (TLR) 2 and P-selectin/P-selectin glycoprotein ligand (PSGL)-1. ${ }^{38}$ This was demonstrated for both Aggregatibacter actinomycetemcomitans and Porphyromonas gingivalis. ${ }^{38}$ Platelets can augment the respiratory burst in neutrophils in response to opsonized Escherichia coli and Staphylococcus aureus. ${ }^{39}$ Platelet-neutrophil complexes have more activated adhesion molecules, greater phagocytic ability, and greater toxic oxygen metabolites than noncomplexed neutrophils. ${ }^{40}$ Activated platelets can also induce superoxide anion release by monocytes and neutrophils through P-selectin. ${ }^{41}$ Soluble CD40 ligand (CD40L) further interacts with CD40 and $\alpha \mathrm{M} \beta 2$ on neutrophils to induce the adhesive functions of neutrophils as well as cause CD40-dependent reactive oxygen species (ROS) generation. ${ }^{42}$

Additionally, the triggering receptor expressed on myeloid cells (TREM)-1 ligand is expressed on platelets and has been shown to induce neutrophil activation, and platelets enhance the neutrophil respiratory burst and release of IL-8 in a TREM-1specific manner in the presence of LPS. ${ }^{43}$ The TREM- 1 receptor is an important receptor in the innate immune response as well as in severe sepsis where it amplifies the immune response to microbial products. ${ }^{44}$ TREM- 1 has also been shown to contribute to neutrophil activation in viral infections. ${ }^{45}$

Furthermore, platelets induce the release of neutrophil extracellular traps (NETs), deoxyribonucleic acid(DNA) covered with various antimicrobial nuclear and granule-derived molecules $^{46}$ that ensnare and kill pathogens, in response to bacterial (septic) stimuli. ${ }^{39,47,48}$ This NET response has been documented in E. coli gram-negative sepsis and $S$. aureus gram-positive sepsis. ${ }^{47}$ Platelets have further been shown to interact with neutrophils following viral challenge, leading to the release of NETs. ${ }^{49-51}$ NETs also deliver antiviral factors such as myeloperoxidase ${ }^{46}$ and $\alpha$-defensin, ${ }^{50}$ and capture viruses and promote their elimination. ${ }^{51}$-Fig. 4 provides an overview of the interactions between platelets and immune cells to emphasize the involvement of platelets in the immune response.

\section{Platelet Involvement in Adaptive Immunity: Ensuring an Optimal Adaptive Response}

Further to the innate immune response, platelets are also important for an optimal adaptive immune response. The periodontopathogens A. actinomycetemcomitans and $P$. gingivalis have been shown to induce expression of CD40L on human platelets via TLR2 and TLR4. ${ }^{52}$ Platelets can modulate B and T cell responses to microbial pathogens through CD40L, and are able to induce isotype switching by B cells and augment $\mathrm{CD} 8^{+} \mathrm{T}$ cell function. ${ }^{53,54} \mathrm{CD} 40 \mathrm{~L}$ on platelets enable $\mathrm{T}$ cell priming and augment $\mathrm{CD}^{+} \mathrm{T}$ cell responses against bacterial pathogens by enhancing maturation signals to dendritic cells and lowering the threshold for cell activation ${ }^{55-57}$ (compare with reports that platelets can have an inhibitory effect on dendritic cells ${ }^{58,59}$ ).

Platelet-mediated modulation of the adaptive immune system has also been shown to enhance protection against viral rechallenge. ${ }^{53}$ Platelets expressing integrin $\beta 3$ and CD40L are essential for lymphocytic choriomeningitis virus (LCMV) clearance by virus-specific cytotoxic T cells, and protect the host from virus-induced interferon- $\alpha / \beta$ lethal hemorrhage. ${ }^{18}$ Activated platelets can also contribute to immunopathology (e.g., liver damage) by accumulating virus-specific cytotoxic T cells at the site of inflammation in models of acute viral hepatitis. ${ }^{60}$ Serotonin released from platelets is vasoactive and can further support viral persistence in the liver by reducing microcirculation, which aggravates virus-induced immunopathology in a model of LCMV-induced hepatitis. ${ }^{61}$

Platelets can further shuttle blood-borne gram-positive bacteria to splenic $\mathrm{CD} 8 \alpha^{+}$dendritic cells after the bacterium becomes associated to platelets via glycoprotein (GP)-Ib and 


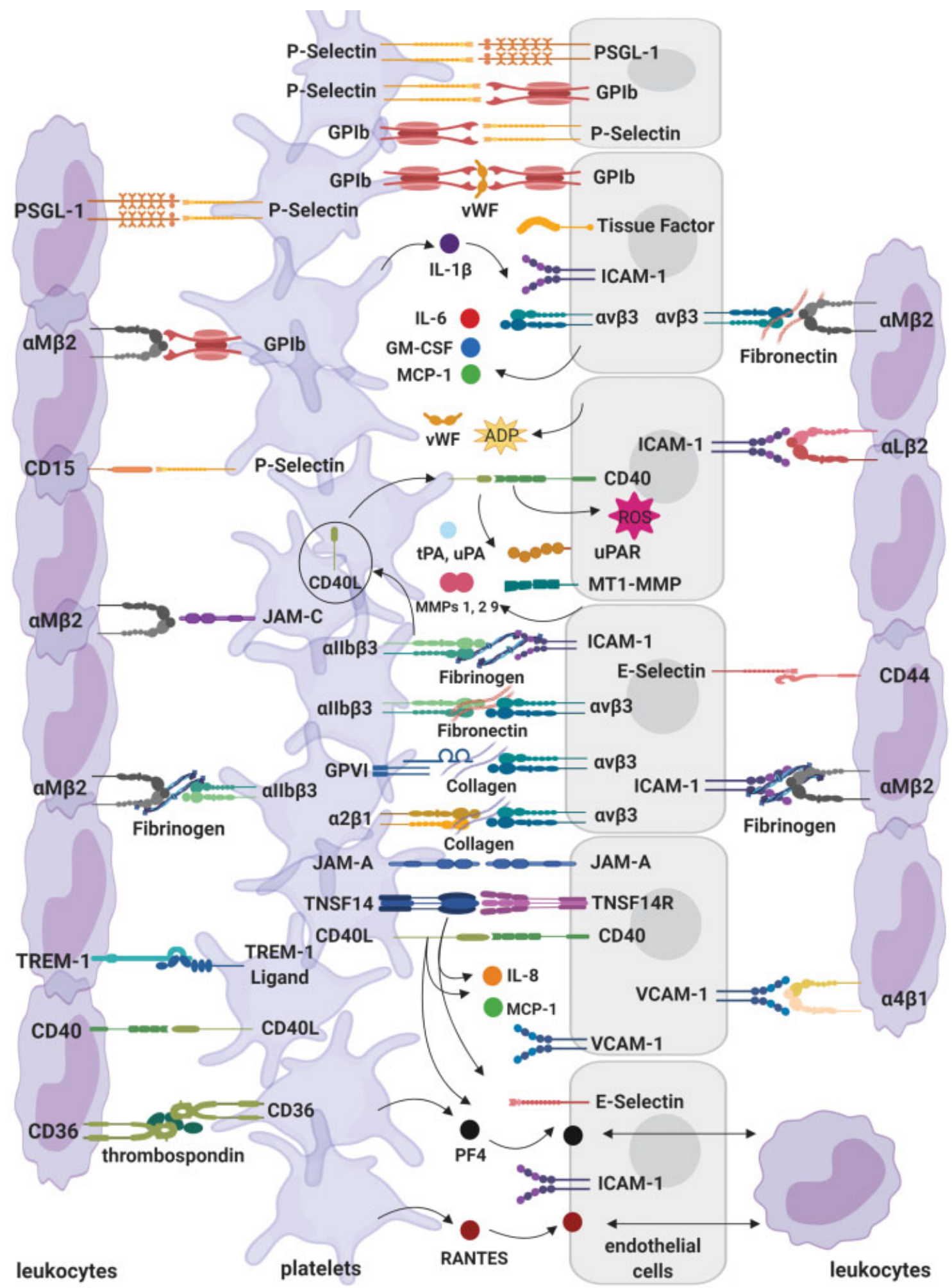

Fig. 3 Platelet interactions at the vascular wall. Platelet activation and adhesion to the vascular wall is facilitated by various receptor interactions with endothelial cells. An inflamed vessel wall will adopt a prothrombotic phenotype and release platelet binding and stimulating agents. The adhesion of platelets activates endothelial cells, and together with potent inflammatory mediators released by platelets induces the expression of integrins, adhesion molecules, and other receptors on the endothelial surface, as well as causes the endothelium to secrete chemokines and other mediators. Platelets similarly bind and activate leukocytes, contributing to leukocyte recruitment to the endothelium. In turn, leukocytes are activated and are able to adhere to the inflamed vessel, with platelets also serving as bridging connections between the endothelium and circulating leukocytes (created with https://biorender.com/). (Adapted from van Gils et $\mathrm{al}^{24}$.) ADP, adenosine diphosphate; GM-CSF, granulocyte-macrophage colony-stimulating factor; ICAM, intercellular adhesion molecule; IL, interleukin; JAM, junction adhesion molecule; MCP, monocyte chemoattractant protein; MMP, matrix metalloproteinase; MTP1-MMP, membrane type-1 MMP; PF, platelet factor; PSGL, P-selectin glycoprotein ligand-1; RANTES, regulated on activation, normal T-cell expressed and secreted; ROS, reactive oxygen species; TNSF14(R), tumor necrosis factor superfamily member 14 (receptor); tPA, tissue plasminogen activator; TREM, triggering receptor expressed on myeloid cells; uPA, urokinase-type plasminogen activator; uPAR, urokinase receptor; VCAM, vascular cell adhesion protein; vWF, von Willebrand factor. 


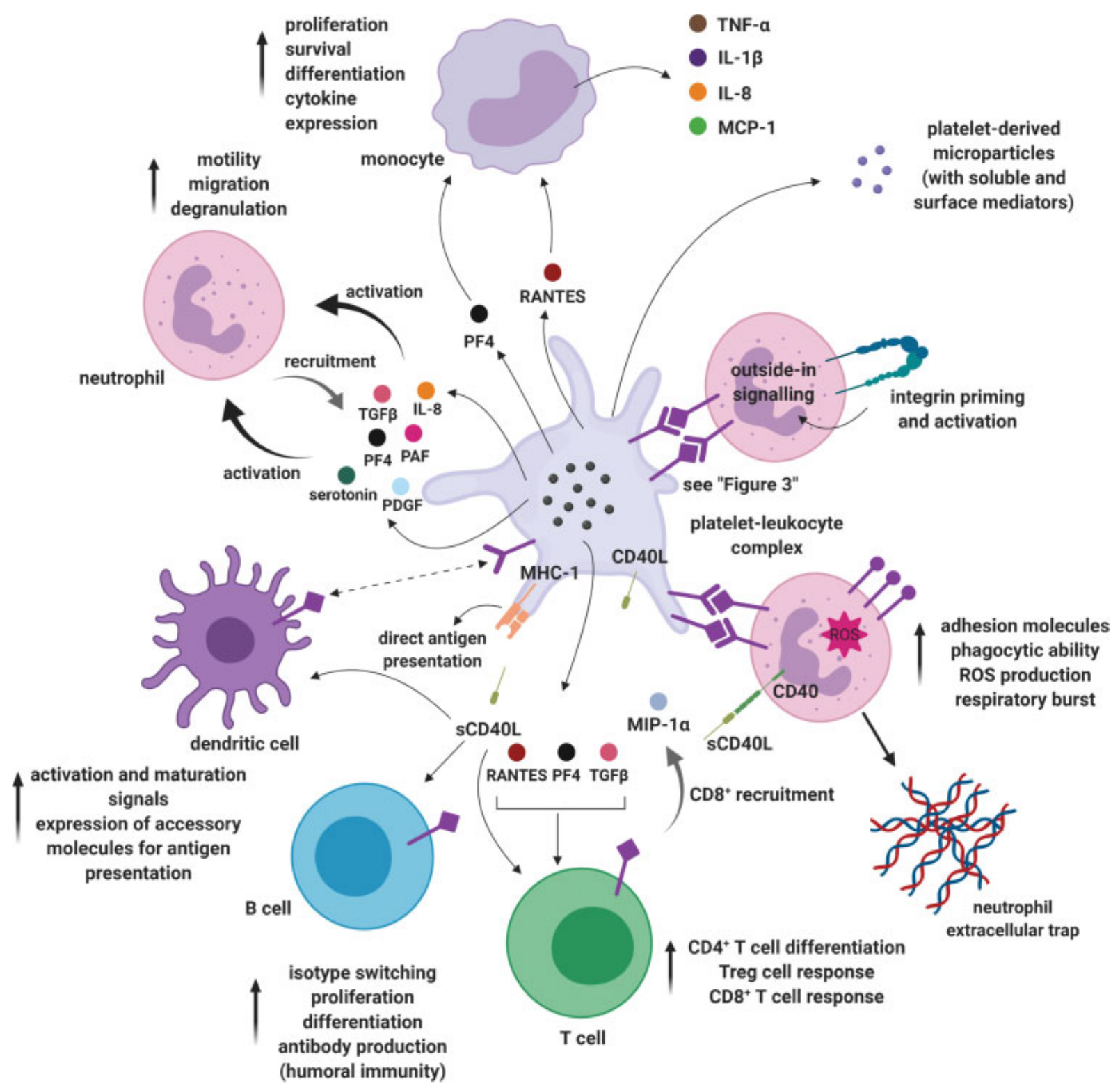

Fig. 4 Platelet interactions with immune cells. Platelets are important contributors to the multifaceted immune response to infection and have the ability to engage the immune system. Degranulation leads to the surface expression of receptors and the release of abundant proinflammatory mediators that regulate leukocytes at the site of infection. Platelets also modulate leukocytes involved in adaptive immunity. Ultimately, platelets promote the effector functions of immune cells and enable an optimal immune response (created with https://biorender. com/). IL, interleukin; MCP, monocyte chemoattractant protein; MHC, major histocompatibility complex; MIP, macrophage inflammatory protein; PAF, platelet-activating factor; PDGF, platelet-derived growth factor; PF, platelet factor; RANTES, regulated on activation, normal T-cell expressed and secreted; ROS, reactive oxygen species; TGF, transforming growth factor; TNF, tumor necrosis factor; Treg, regulatory T cell.

complement C3 to balance bacterial clearance with immune induction. ${ }^{62}$ Activated platelets also form aggregates with $\mathrm{CD}_{16}{ }^{+}$inflammatory monocytes and human leukocyte antigen (HLA)-DR ${ }^{+}$CD38 $8^{+}$memory T cells in human immunodeficiency virus (HIV) infection.?

\section{Platelet-Derived Microparticles: Further Driving the Inflammatory Response}

Activated platelets produce microparticles during bacteri$\mathrm{al}^{63,64}$ and viral infection ${ }^{65,66}$ that contain both soluble (e.g., regulated on activation, normal $\mathrm{T}$ cell expressed and secreted [RANTES]) and surface mediators (e.g., P-selectin, GPIb, and $\alpha$ IIb $\beta 3$ ), which can exit the vasculature and enter tissues where they are able to activate leukocytes to further drive the inflammatory response. ${ }^{67,68}$ For example, platelet microparticles enhance the expression of cell adhesion molecules such as leukocyte $\alpha \mathrm{M} \beta 2$ for monocyte adhesion, ${ }^{69}$ and can mediate leukocyte activation ${ }^{70}$ and leukocyte-leukocyte interactions. ${ }^{71}$ Microparticles promote platelet interaction with the endothelium by acting as a substrate for further platelet binding. ${ }^{72}$ Further, microparticles can deliver platelet-derived CD40L signals ${ }^{54,73}$ and activate dendritic cells. ${ }^{74}$ Platelet microparticles also promote endothelial activation by secreting IL-1 $\beta,{ }^{75}$ and can deliver RANTES to the endothelium for monocyte recruitment. ${ }^{76}$ Lastly, these microparticles can cause complement activation. ${ }^{77}$ 


\section{Platelet Interactions with Bacteria}

Platelets are active role players in antimicrobial defense, and exhibit complex interactions with bacteria and viruses due to the variety of platelet receptors involved in pathogen recognition. Platelets are able to recognize, bind, and internalize pathogens to sequester and neutralize the pathogen. This section describes the interactions of platelets with bacteria, which are summarized in - Fig. $\mathbf{5}$.

\section{Platelet Receptors in Bacterial Pathogen Sensing}

It has long been known that bacteria can cause platelet aggregation and degranulation. ${ }^{78,79} \mathrm{~A}$ diverse range of platelet receptors can mediate interactions with bacteria, including $\alpha \mathrm{IIb} \beta 3$, low-affinity immunoglobulin gamma Fc region receptor II-a (FcrRIIa), GPIb, complement receptors (CRs), and TLRs, ${ }^{80,81}$ either directly or indirectly through bridging molecules. ${ }^{11,12,81}$ Alternatively, products shed by bacteria ${ }^{82}$ may cause a platelet response independently of direct

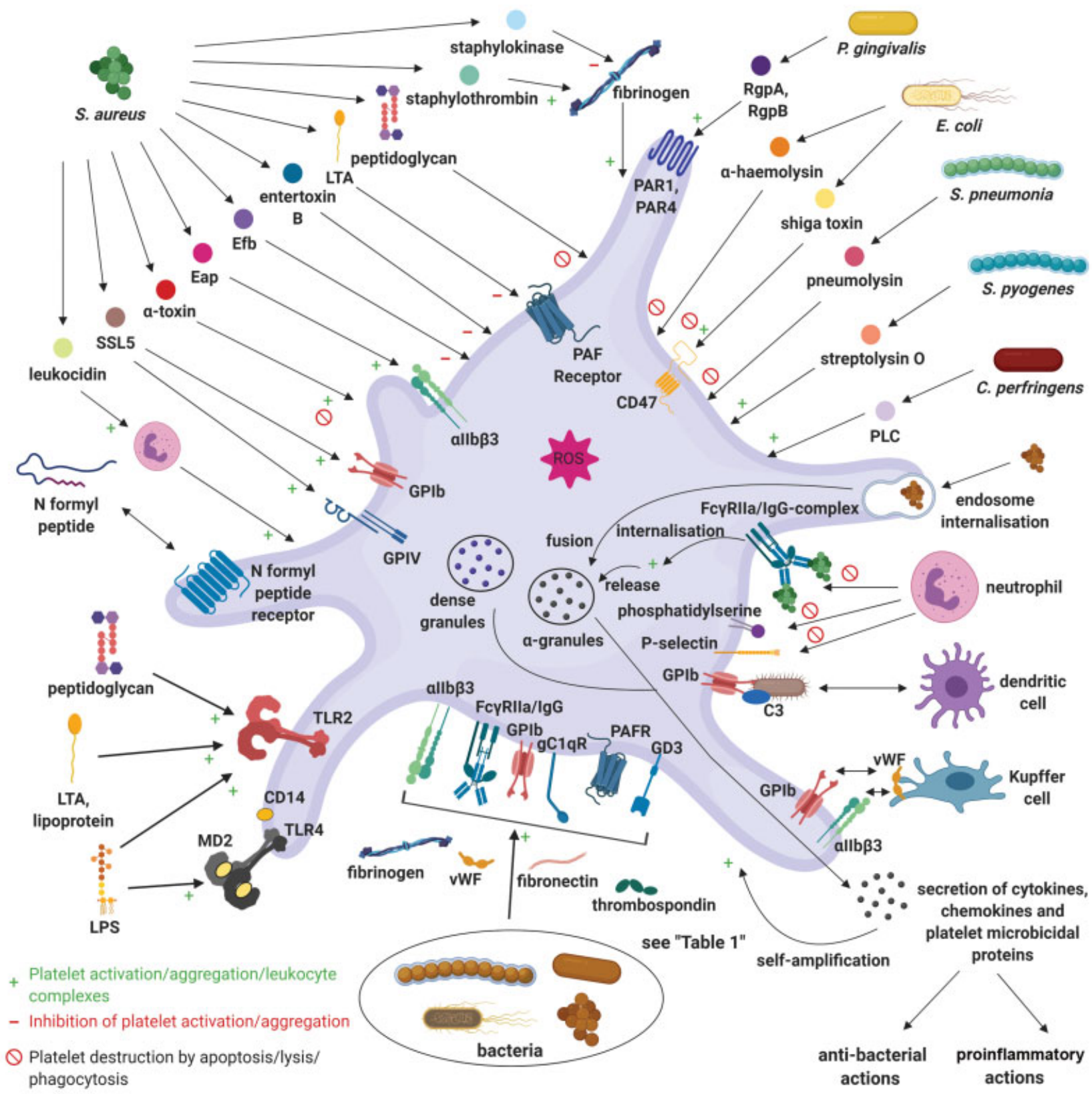

Fig. 5 Platelet interactions with bacteria. Platelets are able to sense and bind bacteria through a variety of platelet receptors, and various bacterial products stimulate platelets, modulating their function. Platelets typically become activated and aggregate, but bacterial products may exert inhibitory actions or cause platelet destruction. Platelets additionally mediate antimicrobial actions by releasing microbicidal proteins, engulfing bacteria, and interacting with immune cells. These interactions further enhance the immune response and lead to platelet clearance (created with https://biorender.com/). C3, complement component 3; Eap, extracellular adherence protein; Efb, extracellular fibrinogen-binding protein; FcyRlla, low-affinity immunoglobulin gamma Fc region receptor II-a; gC1Qr, receptor for the globular heads of C1q; lg, immunoglobulin; LPS, lipopolysaccharide; LTA, lipoteichoic acid; PAF(R), platelet-activating factor (receptor); PAR, platelet-activating factor; PLC, phospholipase C; Rgp, recombinant gingipain; ROS, reactive oxygen species; SSL, staphylococcal superantigen-like; TLR, toll-like receptor; vWF, von Willebrand factor. 
Table 2 Platelet receptors that mediate bacterial adhesion and platelet activation

\begin{tabular}{|c|c|c|c|}
\hline Bacteria & Bacterial component & Platelet receptors/host factors & References \\
\hline Borrelia burgdorferi & & $\alpha \operatorname{llb} \beta 3$ & 182 \\
\hline Chlamydia pneumoniae & & $\alpha \operatorname{llb} \beta 3$ & 183 \\
\hline Helicobacter pylori & & IgG-FcyRIla, GPIb, vWF & 184 \\
\hline Porphyromonas gingivalis & Hgp44 & GPIb, IgG-FcyRIla & 185 \\
\hline Streptococcus agalactiae & FbsA & allbß3, fibrinogen, IgG-FcyRlla & 186 \\
\hline Staphylococcus aureus & ClfA, ClfB, FnBPA, SdrE, SpA, IsdB & 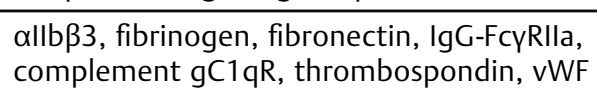 & $84,187-201$ \\
\hline Staphylococcus epidermidis & SdrG & allb $\beta 3$, fibrinogen, IgG- FcyRlla & 202 \\
\hline Streptococcus gordonii & PadA, SspA/SspB, GspB/Hsa & 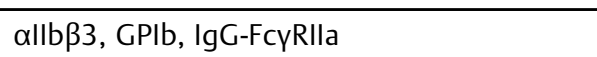 & $84,203-206$ \\
\hline Staphylococcus lugdunensis & Fbl & Fibrinogen & 207 \\
\hline Streptococcus mitis & PblA, PblB, lysin & $\begin{array}{l}\alpha \text { llb } \beta 3 \text {, fibrinogen, } \\
\text { membrane ganglioside GD3 }\end{array}$ & 208,209 \\
\hline Streptococcus oralis & & GPIb, IgG-FcyRIla & 84,210 \\
\hline Streptococcus pneumoniae & Pav, PspC/Hic & 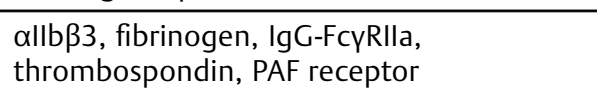 & $84,211-213$ \\
\hline Streptococcus pyogenes & M protein & allbß3, fibrinogen, IgG-FcyRlla & 201,214 \\
\hline Streptococcus sanguis & SrpA & allbß3, fibrinogen, IgG-FcyRlla, GPIb & $84,215-217$ \\
\hline
\end{tabular}

Abbreviations: Clf, clumping factor; FnBPA, fibronectin-binding protein $A ;$ IsdB, iron-regulated surface determinant $B$; PadA, platelet adherence protein A; PavB, pneumococcal adherence and virulence factor B; PspC, pneumococcal surface protein C; Sdr, serine-aspartate repeat protein; SpA, staphylococcal protein A; SrpA, serine-rich protein A; Ssp, stringent starvation protein; vWF, von Willebrand factor.

bacterial attachment to the platelet. ${ }^{10}$ Ultimately, engagement of receptors by bacteria and their products leads to common and species-specific intracellular signaling events in platelets. ${ }^{83}$

- Table 2 summarizes platelet receptors that mediate binding of bacteria to cause platelet activation and aggregation. A key mechanism for bacterial adhesion to platelets, which is described for various bacteria, involves $\alpha$ IIb $\beta 3$ integrin activation, the FcyRIla receptor, and $\operatorname{IgG},{ }^{84}$ where platelet factor (PF)-4 may potentiate further binding of additional bacteria by forming an immunocomplex with bacteria that bind through FcrRIIa. ${ }^{85}$

Platelets also express $\mathrm{C}-\mathrm{C}$ motif and $\mathrm{C}-\mathrm{X}-\mathrm{C}$ motif chemokine receptors such as CCR1, CCR2, CCR4, and CXCR4, ${ }^{86}$ which can detect all four classes of chemokines ( $C, C C, C X C$, and $\mathrm{CX}_{3} \mathrm{C}$ ). These receptors allow platelets to recognize and prioritize chemotactic signals and result in rapid vectoring of platelets to sites of infection. ${ }^{9}$ They are also involved in stimulating platelet adhesion, aggregation, and secretion. ${ }^{87}$ Additionally, platelet activation leads to activation of the complement system, ${ }^{88,89}$ and platelets also express various complement receptors after activation such as CR2, CR3, CR4, C3aR, C5aR, $\mathrm{CC} 1 \mathrm{qR}$, and $\mathrm{gC} 1 \mathrm{qR}$. $^{3}$ These may therefore serve as potential receptors for bacteria coated with complement factors, and lead to platelet aggregation. ${ }^{11}$ Furthermore, an important class of receptors for pathogen sensing are TLRs, and platelets express numerous TLRs to detect the molecular features of microbes. ${ }^{21,90-92}$ Platelets express, among others, functional TLR4, ${ }^{93}$ as well as the accessory component for LPS signaling, including CD14, MD2, and myeloid differentiation primary response (MyD)-88..$^{94}$

\section{Bacterial Products Affect Platelet Functions}

Platelets are able to respond to many bacterial products, and these products modulate platelet function. ${ }^{25}$ LPS can stimulate platelet secretion of dense and $\alpha$-granules through TLR4/ MyD88 and cyclic guanosine monophosphate (cGMP)/cGMPdependent protein kinase (PKG) signaling pathways. ${ }^{94}$ This potentiates secretion-dependent integrin activation and platelet aggregation. Further to this, platelets recognize and discriminate between various isoforms of bacterial LPS and secrete differential cytokine profiles against these danger signals. ${ }^{95,96}$ LPS also induces sCD40L release from platelets ${ }^{97}$ as well as ROS generation. ${ }^{98}$ Some sources of LPS can activate TLR2, ${ }^{99-101}$ and this has also been implicated in LPS-induced cGMP elevation and platelet activation. ${ }^{94}$ However, LPS is described as not always generating conventional platelet activation (e.g., typical P-selectin release from $\alpha$-granules). ${ }^{25}$ Bacterial structures from gram-positive bacteria such as lipoproteins, peptidoglycan, and LTA are TLR2 ligands, and also trigger platelet activation. ${ }^{92,102}$ TLR activation in platelets induces a thromboinflammatory response, including platelet aggregation, formation of platelet-leukocyte complexes, and ROS generation ${ }^{103}$ as well as the elaboration of acutephase reactants like TNF- $\alpha .{ }^{91}$ However, studies have shown mixed effects of TLR2 agonists and LTA on platelet aggregation. 104,105

Platelets can migrate toward the chemotactic signal of bacterial $\mathrm{N}$-formyl peptide by their receptors for this peptide. $^{106}$ The gingipain proteases HRgpA and RgpB from $P$. gingivalis activate platelet protease-activated receptor (PAR)-1 and PAR4, leading to platelet aggregation. ${ }^{107,108}$ $S$. aureus $\alpha$-toxin also causes platelet activation and leads to 
enhanced prothrombinase activity on the platelet surface. ${ }^{109,110}$ Staphylococcal superantigen-like (SSL)-5 from $S$. aureus additionally induces platelet activation via platelet receptors GPVI and GPIb, ${ }^{111,112}$ whereas the Panton-Valentine leukocidin toxin leads to platelet activation via neutrophil secretion products from damaged neutrophils. ${ }^{113}$

Another class of exotoxins from $S$. aureus, extracellular adherence protein (Eap) and extracellular fibrinogen-binding protein (Efb) fibrinogen-binding proteins, also interacts with platelets. On the one hand, Eap enhances $\alpha \operatorname{IIb} \beta 3$ integrin activation, granule secretion, and aggregation, ${ }^{114}$ whereas Efb inhibits platelet activation and aggregation ${ }^{115,116}$ and has powerful antiplatelet actions. ${ }^{117}$ Staphylococcus aureus enterotoxin B similarly inhibits platelet aggregation. ${ }^{118}$ LTA from $S$. aureus has also been reported to inhibit platelet activation through platelet-activating factor (PAF) receptor and raised cyclic adenosine monophosphate (CAMP), ${ }^{119}$ as well as to inhibit platelet aggregation, ${ }^{120-122}$ but may support platelet adhesion to Staphylococcus epidermidis. ${ }^{123}$ Additional products released by $S$. aureus also have opposing functions on platelet aggregation. While staphylothrombin mediates fibrin formation that supports aggregation, ${ }^{124}$ staphylokinase prevents aggregation by degrading fibrinogen. ${ }^{125}$

Bacterial toxins can also cause platelet destruction. For example, $\alpha$-toxin from $S$. aureus and $\alpha$-hemolysin from E. coli $^{126}$ as well as peptidoglycan from $S$. aureus ${ }^{127}$ can induce platelet apoptosis. Indeed, these pore-toxins stimulate disturbances in the platelet membrane and can be cytotoxic. ${ }^{3,128}$ Escherichia coli Shiga toxin causes downregulation of platelet CD47 expression, which leads to enhanced platelet activation and phagocytosis of platelets by macrophages. ${ }^{129}$ Toxins such as pneumolysin from Streptococcus pneumoniae $^{130}$ and $\alpha$-toxin from $S$. aureus ${ }^{131}$ can cause platelet lysis, whereas streptolysin O from Streptococcus pyogenes $^{132}$ and phospholipase $\mathrm{C}$ from Clostridium perfringens $^{133}$ induce the formation of platelet-leukocyte complexes.

\section{Platelets Mediate Antimicrobial Attack}

A further function of platelets in bacterial infection is mediating antimicrobial attack. Platelets mediate some of their antimicrobial actions through the secretion of potent antimicrobial proteins from their $\alpha$-granules. ${ }^{8,35}$ Moreover, platelets rapidly form clusters around bacteria that have been captured by Kupffer cells in the liver sinusoids (specialized macrophages in the liver), encasing the bacterium and facilitating its destruction. ${ }^{13}$ Further, sCD40L causes increased generation and release of reactive oxygen (e.g., superoxide) and nitrogen (e.g., nitric oxide) species by platelets, which assists in pathogen destruction. ${ }^{134,135}$

Platelets are able to bind and endocytose/phagocytose bacteria through engulfing endosome-like vacuoles that are formed by membrane endocytosis and become the site of $\alpha$-granule release for the granular proteins to access the pathogen. ${ }^{136,137}$ A mechanism of internalizing bacteria via the open canalicular system has also been proposed ${ }^{138}$ (compare with Boukour and Cramer $^{139}$ ). Nonetheless, the platelet
FcrRIla receptor can bind IgG complexes and allows platelets to clear these complexes from the circulation. ${ }^{140}$ Internalization of IgG-coated particles results in platelet activation and the release of RANTES and SCD40L. ${ }^{141}$ Platelets opsonized by IgG can be destroyed by Fc-mediated platelet phagocytosis, contributing to the clearance of IgG-containing complexes from the circulation. ${ }^{142,143}$ More broadly, activated platelets expose phosphatidylserine, and neutrophils have been shown to phagocytose activated platelets in a clearance program involving phosphatidylserine and P-selectin. ${ }^{144-146}$

\section{Platelet Interactions with Viruses}

Viruses have been observed to interact directly with platelets. Various viruses have been identified adsorbed to or inside platelets, including influenza virus, ${ }^{147,148} \mathrm{HIV},{ }^{136,149,150}$ hepatitis $C^{151-153}$ and herpes simplex virus ${ }^{154}$ as well as others such as vaccinia virus ${ }^{155}$ and dengue virus. ${ }^{156-158}$ However, the interactions between viruses and platelets are less well characterized compared with those of gram-positive bacteria. This section describes the interaction of platelets with viruses, which are summarized in -Fig. 6.

\section{Platelet Receptors in Viral Pathogen Sensing}

Several platelet receptors have been identified to mediate binding to viral particles, $6,7,30,159$ and are summarized in -Table 3. Similarly to bacteria, IgG is important for the adhesion of viral particles to platelets, where IgG-coated particles can interact with the FcrRIIa receptor ${ }^{151,160-162}$ to be internalized into the platelet. ${ }^{140}$ However, other antibody-dependent mechanisms that enhance viral binding to platelets are also described, ${ }^{156}$ and platelets can further bind viruses in a receptor-independent manner. ${ }^{163}$ For example, although the coxsackievirus and adenovirus receptor (CAR) is expressed on platelets, coxsackie B virus interaction with platelets has also been described independently of CAR and can result in P-selectin and phosphatidylserine exposure. ${ }^{163}$ More broadly, $\beta 3$ integrins are important platelet-adhesion receptors, and these receptors appear to facilitate viral adhesion to platelets. ${ }^{18,65,164}$ Even though various receptors that are expressed on platelets have been implicated in viral adhesion and cell entry, the direct effect of this interaction on the platelet has not always been described.

Platelets can also detect viruses through TLRs. Platelet TLR2 can bind cytomegalovirus, which triggers platelet activation, degranulation, and the formation of plateletleukocyte aggregates. ${ }^{165}$ TLR7 recognizes the classical viral PAMP, single-stranded RNA. ${ }^{92}$ Platelets express functional TLR7, and activation via TLR7 leads to expression of CD40L and P-selectin, and P-selectin supports the adhesion of virally activated platelets to neutrophils. ${ }^{22,166}$ Moreover, platelet TLR7 mediates complement C3 release from platelets, which in turn leads to platelet-neutrophil aggregation and NET release by neutrophils. ${ }^{167}$ Encephalomyocarditis virus has been shown to interact with platelet TLR7. ${ }^{166}$ Platelet TLR9 recognizes unmethylated $\mathrm{CPG}$ islands found in bacterial and viral DNA, which also leads to P-selectin surface expression. ${ }^{92,168}$ 


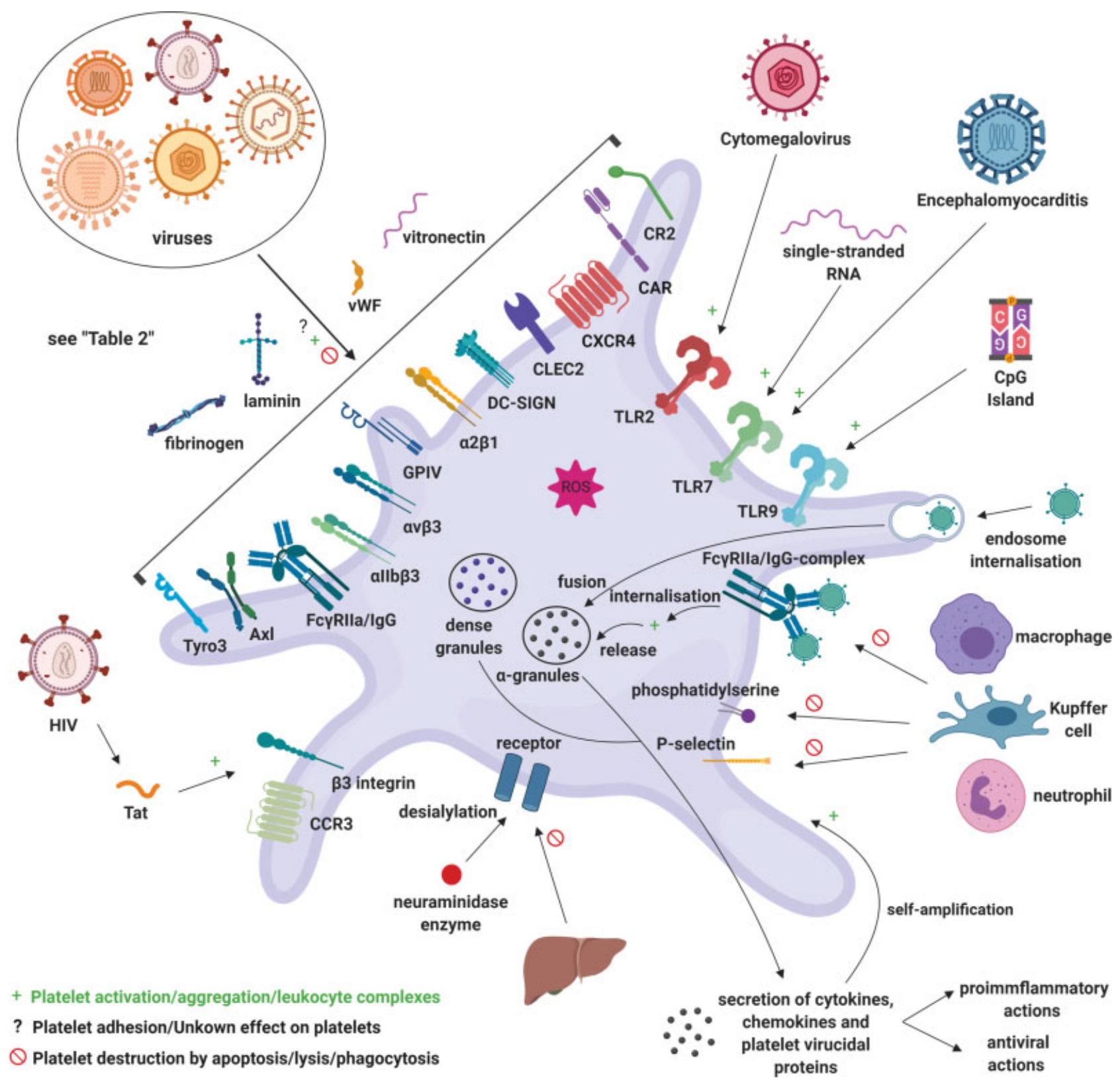

Fig. 6 Platelet interactions with viruses. Various platelet receptors can mediate binding to viral particles; however, the direct effect of this binding on platelets is less well described than for bacteria. Pattern recognition receptors recognize classical viral signals, and viral products also modulate platelet function. Platelets mediate viral attack by secreting virucidal proteins and by engulfing viral particles, as well as by interacting with immune cells and enhancing the immune response. Overall, platelets may be activated and aggregate, but also face apoptosis. Virus-platelet aggregates and platelets with a viral load are targeted by leukocytes, and platelets are ultimately cleared from the circulation (created with https://biorender.com/). CAR, coxsackievirus and adenovirus receptor; CCR/CXCR, chemokine receptor; CLEC, C-type lectin-like receptor; CR, complement receptor; DC-SIGN, dendritic cell-specific ICAMgrabbing nonintegrin; FcyRlla, low-affinity immunoglobulin gamma Fc region receptor II-a; HIV, human immunodeficiency virus; Ig, immunoglobulin; RNA, ribonucleic acid; ROS, reactive oxygen species; Tat, trans-activator of transcription; TLR, toll-like receptor; vWF, von Willebrand factor.

\section{Viral Products Affect Platelet Functions}

Viruses secrete various products that modulate platelet function. The secreted HIV Tat protein directly interacts with platelets in a process requiring the platelet receptors CCR3 and $\beta 3$ integrin as well as calcium influx. This leads to platelet activation and CD40L expression as well as microparticle formation. ${ }^{65}$ Indeed, platelet activation persists even in virologically suppressed HIV infection. ${ }^{169}$ Viral enzymes such as neuraminidase can cause desialylation of platelet surface receptors, ${ }^{6}$ and desialylation might promote platelet clearance in the liver. ${ }^{170,171}$

\section{Platelets Mediate Antiviral Attack}

The secretory products of platelets can also exert virucidal effects, including the inactivation of adenovirus, poliovirus and vaccinia virus, ${ }^{172}$ and HIV suppression. ${ }^{20}$ Moreover, platelets exhibit phagocytic behavior toward viruses such as HIV and can form engulfing vacuoles that lead to granular components being secreted on the virus particle, as described for bacteria. ${ }^{136}$ Indeed, intact HIV-1 particles enclosed in endocytic vesicles have been found in the open canalicular system. ${ }^{173,174}$ Recently, it has been proposed that platelets may also potentially phagocytose influenza virus. ${ }^{175,176}$ Platelets may then 
312 Platelet Dysfunction and Depletion in Infection Page, Pretorius

Table 3 Platelet receptors that mediate viral binding

\begin{tabular}{|c|c|c|c|c|}
\hline Virus & Viral component & Platelet receptors/host factors & Effect on platelet & References \\
\hline Adenoviruses & $\begin{array}{l}\text { Penton base } \\
\text { (RGD ligand site) }\end{array}$ & $\begin{array}{l}\text { Fibrinogen, laminin, vitronectin } \\
\text { and vWF, } \alpha I \beta 3, \alpha v \beta 3 \text {, } \\
\text { CAR receptor }\end{array}$ & $\begin{array}{l}\text { Platelet activation, } \\
\text { platelet-leukocyte } \\
\text { aggregate formation }\end{array}$ & $30,218-221$ \\
\hline Dengue virus & & DC-SIGN & $\begin{array}{l}\text { Platelet activation, } \\
\text { platelet apoptosis }\end{array}$ & $178,222,223$ \\
\hline Ebola virus & & DC-SIGN & & 224 \\
\hline $\begin{array}{l}\text { Enterovirus echovirus } \\
9 \text { strain Barty }\end{array}$ & $\begin{array}{l}\text { VP1 capsid protein } \\
\text { (RGD ligand site) }\end{array}$ & $\alpha v \beta 3$ & & 225 \\
\hline Epstein-Barr virus & & CR2 & Platelet activation & 226 \\
\hline Hantaviruses & & $\alpha l l \beta 3, \alpha v \beta 3$ & & 227 \\
\hline Hepatitis C virus & & GPVI & & 228 \\
\hline HIV & $\begin{array}{l}\text { Mannose-type } \\
\text { carbohydrates }\end{array}$ & CXCR4, DC-SIGN, CLEC2 & & $174,229,230$ \\
\hline Herpes simplex virus-1 & & $\alpha v \beta 3$ & & 231 \\
\hline Human parechovirus-1 & $\begin{array}{l}\text { VP1 capsid protein } \\
\text { (RGD ligand site) }\end{array}$ & $\alpha v \beta 3$ & & 232 \\
\hline Lassa virus & & DC-SIGN, AxI, Tyro3 & & 233 \\
\hline Rotavirus & $\begin{array}{l}\text { Spike protein VP4 } \\
\text { (DGE ligand site) }\end{array}$ & $\alpha 2 \beta 1$ & & 234,235 \\
\hline
\end{tabular}

Abbreviations: CLEC2, C-type lectin-like receptor 2; DC-SIGN, dendritic cell-specific ICAM-grabbing nonintegrin; DGE, Asp-Gly-Glu tripeptide; HIV, human immunodeficiency virus; RGD, Arg-Gly-Asp tripeptide; VP, viral (capsid) protein; vWF, von Willebrand factor.

cause disruption of viral integrity. ${ }^{174}$ Overall, it has been suggested that internalization of viral particles by platelets may function to clear viruses from the circulation. ${ }^{177}$

Viruses can cause the expression of P-selectin and phosphatidylserine exposure on platelets, and these components promote interactions with leukocytes as well as lead to phagocytosis of the platelet. ${ }^{163,178}$ Interaction between platelets and viruses can also lead to sequestration to the reticuloendothelial system of the liver, where virus-platelet aggregates can be taken up by Kupffer cells and degraded. ${ }^{179}$ Spleen macrophages also assist in clearing platelets with a viral load. ${ }^{30}$

\section{Conclusion}

Platelets are among the first cells to accumulate at sites of infection and inflammation, and can be considered as first responders to invading pathogens. Here, platelets have a key role in sensing and effecting the first wave of responses to microbial and viral threat. ${ }^{8,9}$ This is achieved by the inflammatory activity of platelets but also through direct antibacterial and antiviral actions that facilitate the clearance of pathogens from the circulation. Platelets are therefore represented at the interface of hemostasis, inflammation, and antimicrobial host defense. Their position at the crossroads of these processes emphasizes their role as signaling entities in infection and inflammation.

Various stimuli that are relevant to infection impinge on platelets, activating and forcing them to exert their effector actions. Recursive stimulation of activation receptors and successive activation of bystander platelets intensify the hostdefense functions of platelets even at threshold stoichiometric ratios of platelets to pathogens. ${ }^{180}$ Platelets face inappropriate activation and immunological destruction, and are inevitably consumed by their participation in host defense. An inflammatory milieu can thereby drive platelet dysfunction. In this review, we emphasize that platelet dysfunction can arise as a general consequence of an exaggerated systemic (immune) response to infection. Increased platelet consumption and removal can lead to thrombocytopenia, which is frequently observed during infection. - Fig. 7 summarizes and links together the various processes we have discussed, to show a general mechanism of platelet depletion during infection.

Because of their largely protective role, lower platelet counts are associated with worse prognosis and greater likelihood of infection; however, platelets are also presented as having an ambivalent role in infections by possibly sheltering pathogens in certain cases. $6,7,9,12,30,181$ Nonetheless, in the context of impairment of the immune system, the functions of platelets become more important. Following the contribution of platelets to diverse immunological processes, dysregulation of platelet-leukocyte interactions, which are important for inflammatory and immune reactions, together with dysregulation of inflammatory mediators, establish an excessive and unbalanced systemic inflammatory response. In this context, platelets can contribute to pathophysiological processes and immunopathology, and become dysfunctional.

Achieving a balance between pro- and anti-inflammatory responses during infection is difficult to manipulate 


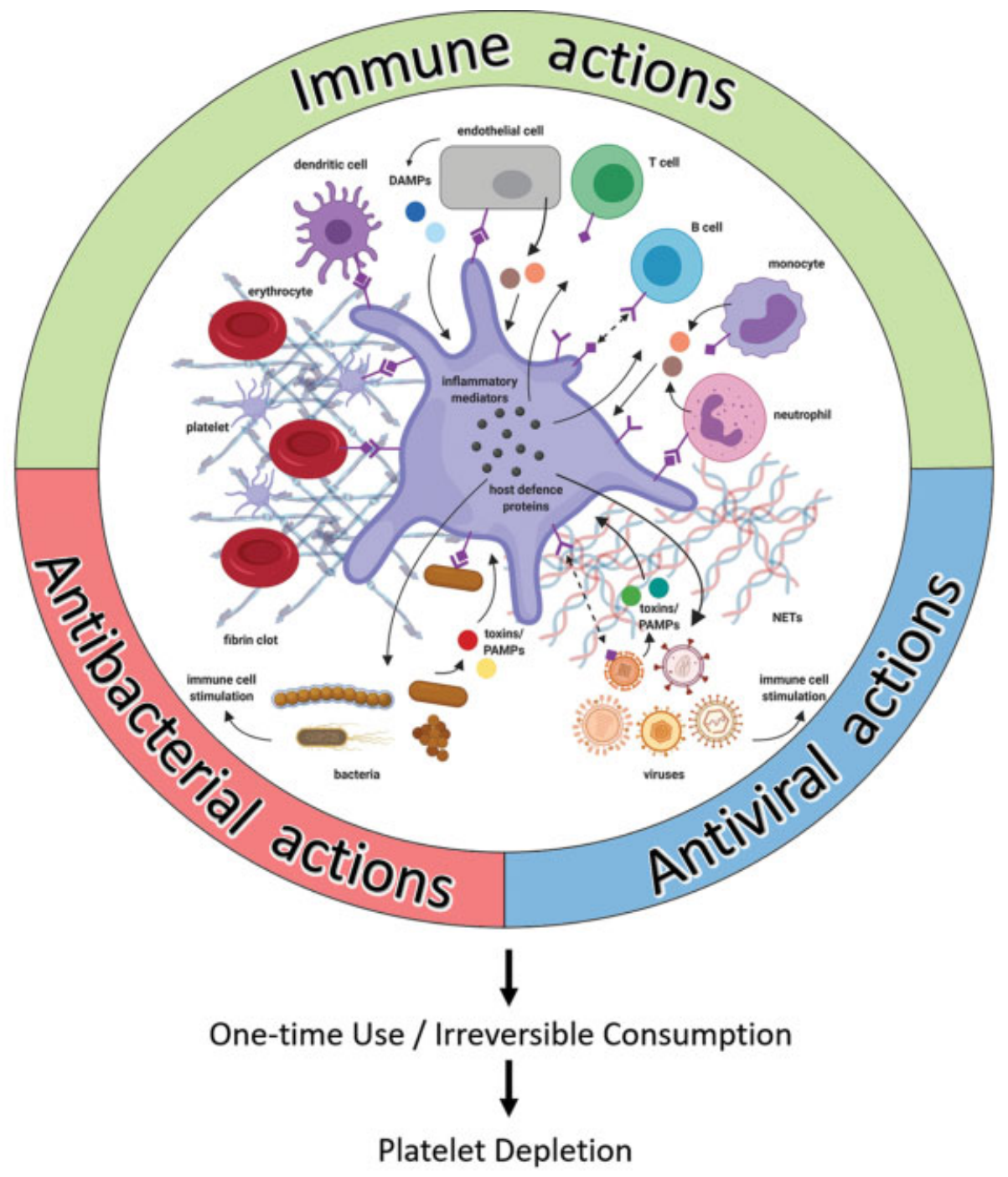

Fig. 7 A generic large-scale cause for platelet dysfunction and depletion in infection. Platelets are intimately involved in the immune and host defense response to infection, where various stimuli challenge the platelet. Platelets operate in close connection with other cells and processes. Platelets are cells of one-time use, and their involvement in the diverse and interconnected processes against infection leads to their irreversible consumption. In the context of abundant stimulation, inappropriate and excessive activation of platelets results in their expenditure and exhaustion (created with https://biorender.com/). (Adapted from Yeaman. ${ }^{9}$ ) DAMP, damage-associated molecular pattern; NET, neutrophil extracellular trap; PAMP, pathogen-associated molecular pattern.

Table 4 Key points

- Platelets are versatile cells positioned at the interface of hemostasis, inflammation, and antimicrobial host defense, and their immune, antibacterial, and antiviral actions establish them as active participants in infection.

- By nature of their normal functioning, platelets are invariably and irreversibly expended in the processes to which they contribute.

- During infection, an onslaught of inflammatory and pathogen-derived stimuli can evoke and challenge platelets, leading to inappropriate activation, immunological destruction, and sequestration.

- In the context of a dysregulated host response to infection, platelets can experience overwhelming activation and, consequently, consumption, and this represents a generic large-scale mechanism for platelet depletion in infection. effectively in a therapeutic context. Following from the diverse functions of platelets in infections, platelets are also placed at an interface between health and disease. Platelets are acutely affected by the surrounding environment. This, together with other characteristics of platelets such as their fast turnover, might position platelets as relevant signaling entities with clinical potential in disease tracking and targeting to evaluate or manage the course of infections. Although platelets are perhaps a lesser-known participant in the host-defense system, their large-scale depletion may cause significant health issues. Managing a generic depletion of platelets during the presence of infection should possibly be a more actively pursued clinical goal. The key points encapsulating the main ideas of this review are presented in -Table 4. 


\section{Author Contribution Statement}

M.P.: wrote paper, prepared figures; E.P.: wrote parts of the paper, study leader, and corresponding author. Both authors edited and reviewed the manuscript.

\section{Conflicts of Interest}

The authors have no competing interests to declare. Mr. Page is supported by the Skye Foundation and the Harry Crossley Foundation. Dr. Pretorius reports grants from the Medical Research Council of South Africa.

\section{Acknowledgments}

We thank the Medical Research Council of South Africa (Self-Initiated Research Program) for supporting our research. The funders had no role in the design and preparation of the manuscript or decision to publish.

\section{References}

1 Semple JW, Freedman J. Platelets and innate immunity. Cell Mol Life Sci 2010;67(04):499-511

2 Semple JW, Italiano JE Jr, Freedman J. Platelets and the immune continuum. Nat Rev Immunol 2011;11(04):264-274

3 Speth C, Löffler J, Krappmann S, Lass-Flörl C, Rambach G. Platelets as immune cells in infectious diseases. Future Microbiol 2013;8(11):1431-1451

4 Weyrich AS, Zimmerman GA. Platelets: signaling cells in the immune continuum. Trends Immunol 2004;25(09):489-495

5 Jenne $\mathrm{CN}$, Kubes P. Platelets in inflammation and infection. Platelets 2015;26(04):286-292

6 Assinger A. Platelets and infection - an emerging role of platelets in viral infection. Front Immunol 2014;5:649

7 Hottz ED, Bozza FA, Bozza PT. Platelets in immune response to virus and immunopathology of viral infections. Front Med (Lausanne) 2018;5:121

8 Yeaman MR. Platelets in defense against bacterial pathogens. Cell Mol Life Sci 2010;67(04):525-544

9 Yeaman MR. Platelets: at the nexus of antimicrobial defence. Nat Rev Microbiol 2014;12(06):426-437

10 Fitzgerald JR, Foster TJ, Cox D. The interaction of bacterial pathogens with platelets. Nat Rev Microbiol 2006;4(06):445-457

11 Hamzeh-Cognasse H, Damien P, Chabert A, Pozzetto B, Cognasse F, Garraud O. Platelets and infections - complex interactions with bacteria. Front Immunol 2015;6:82

12 Cox D, Kerrigan SW, Watson SP. Platelets and the innate immune system: mechanisms of bacterial-induced platelet activation. J Thromb Haemost 2011;9(06):1097-1107

13 Wong CHY, Jenne CN, Petri B, Chrobok NL, Kubes P. Nucleation of platelets with blood-borne pathogens on Kupffer cells precedes other innate immunity and contributes to bacterial clearance. Nat Immunol 2013;14(08):785-792

14 Sullam PM, Frank U, Yeaman MR, Täuber MG, Bayer AS, Chambers HF. Effect of thrombocytopenia on the early course of streptococcal endocarditis. J Infect Dis 1993;168(04):910-914

15 Zhang X, Liu Y, Gao Y, et al. Inhibiting platelets aggregation could aggravate the acute infection caused by Staphylococcus aureus. Platelets 2011;22(03):228-236

16 Claushuis TAM, van Vught LA, Scicluna BP, et al; Molecular Diagnosis and Risk Stratification of Sepsis Consortium. Thrombocytopenia is associated with a dysregulated host response in critically ill sepsis patients. Blood 2016;127(24): 3062-3072

17 Dewitte A, Lepreux S, Villeneuve J, et al. Blood platelets and sepsis pathophysiology: a new therapeutic prospect in critically ill patients? Ann Intensive Care 2017;7(01):115
18 Iannacone $M$, Sitia $G$, Isogawa $M$, et al. Platelets prevent IFN- $\alpha / \beta$ induced lethal hemorrhage promoting CTL-dependent clearance of lymphocytic choriomeningitis virus. Proc Natl Acad Sci U S A 2008;105(02):629-634

19 Loria GD, Romagnoli PA, Moseley NB, Rucavado A, Altman JD. Platelets support a protective immune response to LCMV by preventing splenic necrosis. Blood 2013;121(06):940-950

20 Solomon Tsegaye T, Gnirß K, Rahe-Meyer N, et al. Platelet activation suppresses HIV-1 infection of T cells. Retrovirology 2013;10:48

21 D' Atri LP, Schattner M. Platelet toll-like receptors in thromboinflammation. Front Biosci 2017;22:1867-1883

22 Jenne CN. Platelets: crossroads of immunity and hemostasis. Blood 2014;124(05):671-672

23 Li Z, Delaney MK, O’Brien KA, Du X. Signaling during platelet adhesion and activation. Arterioscler Thromb Vasc Biol 2010;30 (12):2341-2349

24 van Gils JM, Zwaginga JJ, Hordijk PL. Molecular and functional interactions among monocytes, platelets, and endothelial cells and their relevance for cardiovascular diseases. J Leukoc Biol 2009;85(02):195-204

25 Shannon O. Platelet interaction with bacterial toxins and secreted products. Platelets 2015;26(04):302-308

26 Zhang W, Nardi MA, Borkowsky W, Li Z, Karpatkin S. Role of molecular mimicry of hepatitis $C$ virus protein with platelet GPIIla in hepatitis C-related immunologic thrombocytopenia. Blood 2009;113(17):4086-4093

27 Aref S, Sleem T, El Menshawy N, et al. Antiplatelet antibodies contribute to thrombocytopenia associated with chronic hepatitis C virus infection. Hematology 2009;14(05):277-281

28 Olumuyiwa-Akeredolu OO, Page MJ, Soma P, Pretorius E. Platelets: emerging facilitators of cellular crosstalk in rheumatoid arthritis. Nat Rev Rheumatol 2019;15(04):237-248

29 Franchini M, Veneri D, Lippi G. Thrombocytopenia and infections. Expert Rev Hematol 2017;10(01):99-106

30 Flaujac C, Boukour S, Cramer-Bordé E. Platelets and viruses: an ambivalent relationship. Cell Mol Life Sci 2010;67(04):545-556

31 Larkin CM, Santos-Martinez M-J, Ryan T, Radomski MW. Sepsisassociated thrombocytopenia. Thromb Res 2016;141:11-16

32 Tosi MF. Innate immune responses to infection. J Allergy Clin Immunol 2005;116(02):241-249, quiz 250

33 McNicol A, Agpalza A, Jackson EC, Hamzeh-Cognasse H, Garraud $\mathrm{O}$, Cognasse F. Streptococcus sanguinis-induced cytokine release from platelets. J Thromb Haemost 2011;9(10):2038-2049

34 Page AV, Liles WC. Biomarkers of endothelial activation/dysfunction in infectious diseases. Virulence 2013;4(06):507-516

35 Yeaman MR. The role of platelets in antimicrobial host defense. Clin Infect Dis 1997;25(05):951-968, quiz 969-970

36 Sugiyama MG, Gamage A, Zyla R, et al. Influenza virus infection induces platelet-endothelial adhesion which contributes to lung injury. J Virol 2015;90(04):1812-1823

37 Gawaz M, Langer H, May AE. Platelets in inflammation and atherogenesis. J Clin Invest 2005;115(12):3378-3384

38 Assinger A, Laky M, Schabbauer G, et al. Efficient phagocytosis of periodontopathogens by neutrophils requires plasma factors, platelets and TLR2. J Thromb Haemost 2011;9(04):799-809

39 Miedzobrodzki J, Panz T, Płonka PM, et al. Platelets augment respiratory burst in neutrophils activated by selected species of gram-positive or gram-negative bacteria. Folia Histochem Cytobiol 2008;46(03):383-388

40 Peters MJ, Dixon G, Kotowicz KT, Hatch DJ, Heyderman RS, Klein NJ. Circulating platelet-neutrophil complexes represent a subpopulation of activated neutrophils primed for adhesion, phagocytosis and intracellular killing. Br J Haematol 1999;106(02): 391-399

41 Nagata K, Tsuji T, Todoroki N, et al. Activated platelets induce superoxide anion release by monocytes and neutrophils through P-selectin (CD62). J Immunol 1993;151(06):3267-3273 
42 Jin R, Yu S, Song Z, et al. Soluble CD40 ligand stimulates CD40dependent activation of the $\beta 2$ integrin Mac- 1 and protein kinase $C$ zeda (PKC $)$ in neutrophils: implications for neutrophil-platelet interactions and neutrophil oxidative burst. PLoS One 2013;8 (06):e64631

43 Haselmayer P, Grosse-Hovest L, von Landenberg P, Schild H, Radsak MP. TREM-1 ligand expression on platelets enhances neutrophil activation. Blood 2007;110(03):1029-1035

44 Bouchon A, Facchetti F, Weigand MA, Colonna M. TREM-1 amplifies inflammation and is a crucial mediator of septic shock. Nature 2001;410(6832):1103-1107

45 Mohamadzadeh M, Coberley SS, Olinger GG, et al. Activation of triggering receptor expressed on myeloid cells- 1 on human neutrophils by marburg and ebola viruses. J Virol 2006;80(14): 7235-7244

46 Brinkmann V, Reichard U, Goosmann C, et al. Neutrophil extracellular traps kill bacteria. Science 2004;303(5663):1532-1535

47 McDonald B, Urrutia R, Yipp BG, Jenne CN, Kubes P. Intravascular neutrophil extracellular traps capture bacteria from the bloodstream during sepsis. Cell Host Microbe 2012;12(03):324-333

48 Ma AC, Kubes P. Platelets, neutrophils, and neutrophil extracellular traps (NETs) in sepsis. J Thromb Haemost 2008;6(03): 415-420

49 Jenne $\mathrm{CN}$, Wong $\mathrm{CH}$, Zemp FJ, et al. Neutrophils recruited to sites of infection protect from virus challenge by releasing neutrophil extracellular traps. Cell Host Microbe 2013;13(02):169-180

50 Urban CF, Ermert D, Schmid M, et al. Neutrophil extracellular traps contain calprotectin, a cytosolic protein complex involved in host defense against Candida albicans. PLoS Pathog 2009;5 (10):e1000639

51 Saitoh T, Komano J, Saitoh Y, et al. Neutrophil extracellular traps mediate a host defense response to human immunodeficiency virus-1. Cell Host Microbe 2012;12(01):109-116

52 Assinger A, Laky M, Badrnya S, Esfandeyari A, Volf I. Periodontopathogens induce expression of $\mathrm{CD} 40 \mathrm{~L}$ on human platelets via TLR2 and TLR4. Thromb Res 2012;130(03):e73-e78

53 Elzey BD, Tian J, Jensen RJ, et al. Platelet-mediated modulation of adaptive immunity. A communication link between innate and adaptive immune compartments. Immunity 2003;19(01):9-19

54 Sowa JM, Crist SA, Ratliff TL, Elzey BD. Platelet influence on T- and B-cell responses. Arch Immunol Ther Exp (Warsz) 2009;57(04): 235-241

55 Elzey BD, Schmidt NW, Crist SA, et al. Platelet-derived CD154 enables T-cell priming and protection against Listeria monocytogenes challenge. Blood 2008;111(07):3684-3691

56 Kaneider NC, Kaser A, Tilg H, Ricevuti G, Wiedermann CJ. CD40 ligand-dependent maturation of human monocyte-derived dendritic cells by activated platelets. Int J Immunopathol Pharmacol 2003;16(03):225-231

57 Czapiga M, Kirk AD, Lekstrom-Himes J. Platelets deliver costimulatory signals to antigen-presenting cells: a potential bridge between injury and immune activation. Exp Hematol 2004;32 (02):135-139

58 Kissel K, Berber S, Nockher A, Santoso S, Bein G, Hackstein H. Human platelets target dendritic cell differentiation and production of proinflammatory cytokines. Transfusion 2006;46(05): 818-827

59 Hamzeh-Cognasse H, Cognasse F, Palle S, et al. Direct contact of platelets and their released products exert different effects on human dendritic cell maturation. BMC Immunol 2008;9:54

60 Iannacone $M$, Sitia $G$, Isogawa $M$, et al. Platelets mediate cytotoxic T lymphocyte-induced liver damage. Nat Med 2005;11(11):1167-1169

61 Lang PA, Contaldo C, Georgiev P, et al. Aggravation of viral hepatitis by platelet-derived serotonin. Nat Med 2008;14(07): 756-761

62 Verschoor A, Neuenhahn M, Navarini AA, et al. A plateletmediated system for shuttling blood-borne bacteria to $C D 8 \alpha+$ dendritic cells depends on glycoprotein GPIb and complement C3. Nat Immunol 2011;12(12):1194-1201

63 Ogura H, Kawasaki T, Tanaka H, et al. Activated platelets enhance microparticle formation and platelet-leukocyte interaction in severe trauma and sepsis. J Trauma 2001;50(05):801-809

64 Ge S, Hertel B, Emden SH, et al. Microparticle generation and leucocyte death in Shiga toxin-mediated HUS. Nephrol Dial Transplant 2012;27(07):2768-2775

65 Wang J, Zhang W, Nardi MA, Li Z. HIV-1 Tat-induced platelet activation and release of CD154 contribute to HIV-1-associated autoimmune thrombocytopenia. J Thromb Haemost 2011;9(03): 562-573

66 Mayne E, Funderburg NT, Sieg SF, et al. Increased platelet and microparticle activation in HIV infection: upregulation of Pselectin and tissue factor expression. J Acquir Immune Defic Syndr 2012;59(04):340-346

67 Boilard E, Nigrovic PA, Larabee K, et al. Platelets amplify inflammation in arthritis via collagen-dependent microparticle production. Science 2010;327(5965):580-583

68 Nomura S. Function and clinical significance of platelet-derived microparticles. Int J Hematol 2001;74(04):397-404

69 Barry OP, Praticò D, Savani RC, FitzGerald GA. Modulation of monocyte-endothelial cell interactions by platelet microparticles. J Clin Invest 1998;102(01):136-144

70 Lo S-C, Hung C-Y, Lin D-T, Peng H-C, Huang T-F. Involvement of platelet glycoprotein Ib in platelet microparticle mediated neutrophil activation. J Biomed Sci 2006;13(06):787-796

71 Forlow SB, McEver RP, Nollert MU. Leukocyte-leukocyte interactions mediated by platelet microparticles under flow. Blood 2000;95(04):1317-1323

72 Merten M, Pakala R, Thiagarajan P, Benedict CR. Platelet microparticles promote platelet interaction with subendothelial matrix in a glycoprotein IIb/IIla-dependent mechanism. Circulation 1999;99(19):2577-2582

73 Sprague DL, Elzey BD, Crist SA, Waldschmidt TJ, Jensen RJ, Ratliff TL. Platelet-mediated modulation of adaptive immunity: unique delivery of CD154 signal by platelet-derived membrane vesicles. Blood 2008;111(10):5028-5036

74 Nomura S, Fujita S, Nakanishi T, et al. Platelet-derived microparticles cause CD154-dependent activation of dendritic cells. Platelets 2012;23(01):81-82

75 Brown GT, McIntyre TM. Lipopolysaccharide signaling without a nucleus: kinase cascades stimulate platelet shedding of proinflammatory IL-1 $\beta$-rich microparticles. J Immunol 2011;186(09): 5489-5496

76 Mause SF, von Hundelshausen P, Zernecke A, Koenen RR, Weber C. Platelet microparticles: a transcellular delivery system for RANTES promoting monocyte recruitment on endothelium. Arterioscler Thromb Vasc Biol 2005;25(07):1512-1518

77 Yin W, Ghebrehiwet B, Peerschke EI. Expression of complement components and inhibitors on platelet microparticles. Platelets 2008;19(03):225-233

78 Clawson CC, White JG. Platelet interaction with bacteria. I. Reaction phases and effects of inhibitors. Am J Pathol 1971;65 (02):367-380

79 Clawson CC, Rao GH, White JG. Platelet interaction with bacteria. IV. Stimulation of the release reaction. Am J Pathol 1975;81(02): 411-420

80 Ali RA, Wuescher LM, Worth RG. Platelets: essential components of the immune system. Curr Trends Immunol 2015;16:65-78

81 Kerrigan SW. The expanding field of platelet-bacterial interconnections. Platelets 2015;26(04):293-301

82 Mirlashari MR, Hagberg IA, Lyberg T. Platelet-platelet and platelet-leukocyte interactions induced by outer membrane vesicles from N. meningitidis. Platelets 2002;13(02):91-99

$83 \mathrm{McNicol}$ A. Bacteria-induced intracellular signalling in platelets. Platelets 2015;26(04):309-316 
84 Arman M, Krauel K, Tilley DO, et al. Amplification of bacteriainduced platelet activation is triggered by FcrRIIA, integrin $\alpha \mathrm{IIb} \beta 3$, and platelet factor 4. Blood 2014;123(20):3166-3174

85 Naik UP. Bacteria exploit platelets. Blood 2014;123(20):3067-3068

86 Clemetson KJ, Clemetson JM, Proudfoot AE, Power CA, Baggiolini $\mathrm{M}$, Wells TN. Functional expression of CCR1, CCR3, CCR4, and CXCR4 chemokine receptors on human platelets. Blood 2000;96 (13):4046-4054

87 Gear AR, Camerini D. Platelet chemokines and chemokine receptors: linking hemostasis, inflammation, and host defense. Microcirculation 2003;10(3-4):335-350

88 Del Conde I, Crúz MA, Zhang H, López JA, Afshar-Kharghan V. Platelet activation leads to activation and propagation of the complement system. J Exp Med 2005;201(06):871-879

89 Peerschke EIB, Yin W, Ghebrehiwet B. Platelet mediated complement activation. Adv Exp Med Biol 2008;632:81-91

90 Cognasse F, Hamzeh H, Chavarin P, Acquart S, Genin C, Garraud O. Evidence of Toll-like receptor molecules on human platelets. Immunol Cell Biol 2005;83(02):196-198

91 Aslam R, Speck ER, Kim M, et al. Platelet Toll-like receptor expression modulates lipopolysaccharide-induced thrombocytopenia and tumor necrosis factor-alpha production in vivo. Blood 2006;107(02):637-641

92 Garraud O, Cognasse F. Platelet Toll-like receptor expression: the link between "danger" ligands and inflammation. Inflamm Allergy Drug Targets 2010;9(05):322-333

93 Andonegui G, Kerfoot SM, McNagny K, Ebbert KV, Patel KD, Kubes P. Platelets express functional Toll-like receptor-4. Blood 2005; 106(07):2417-2423

94 Zhang G, Han J, Welch EJ, et al. Lipopolysaccharide stimulates platelet secretion and potentiates platelet aggregation via TLR4/MyD88 and the cGMP-dependent protein kinase pathway. J Immunol 2009;182 (12):7997-8004

95 Berthet J, Damien P, Hamzeh-Cognasse H, et al. Human platelets can discriminate between various bacterial LPS isoforms via TLR4 signaling and differential cytokine secretion. Clin Immunol 2012;145(03):189-200

96 Cognasse F, Hamzeh-Cognasse $\mathrm{H}$, Lafarge S, et al. Toll-like receptor 4 ligand can differentially modulate the release of cytokines by human platelets. Br J Haematol 2008;141(01):84-91

97 Cognasse F, Lafarge S, Chavarin P, Acquart S, Garraud O. Lipopolysaccharide induces $\mathrm{SCD} 40 \mathrm{~L}$ release through human platelets TLR4, but not TLR2 and TLR9. Intensive Care Med 2007;33(02): 382-384

98 Zielinski T, Wachowicz B, Saluk-Juszczak J, Kaca W. The generation of superoxide anion in blood platelets in response to different forms of Proteus mirabilis lipopolysaccharide: effects of staurosporin, wortmannin, and indomethacin. Thromb Res 2001;103 (02):149-155

99 Werts C, Tapping RI, Mathison JC, et al. Leptospiral lipopolysaccharide activates cells through a TLR2-dependent mechanism. Nat Immunol 2001;2(04):346-352

100 Darveau RP, Pham TT, Lemley K, et al. Porphyromonas gingivalis lipopolysaccharide contains multiple lipid A species that functionally interact with both toll-like receptors 2 and 4 . Infect Immun 2004;72(09):5041-5051

101 Erridge C, Pridmore A, Eley A, Stewart J, Poxton IR. Lipopolysaccharides of Bacteroides fragilis, Chlamydia trachomatis and Pseudomonas aeruginosa signal via toll-like receptor 2. J Med Microbiol 2004;53(Pt 8):735-740

102 Keane C, Tilley D, Cunningham A, et al. Invasive Streptococcus pneumoniae trigger platelet activation via Toll-like receptor 2 . J Thromb Haemost 2010;8(12):2757-2765

103 Blair P, Rex S, Vitseva O, et al. Stimulation of Toll-like receptor 2 in human platelets induces a thromboinflammatory response through activation of phosphoinositide 3-kinase. Circ Res 2009; 104(03):346-354
104 Kälvegren H, Skoglund C, Helldahl C, Lerm M, Grenegård M, Bengtsson T. Toll-like receptor 2 stimulation of platelets is mediated by purinergic P2X1-dependent $\mathrm{Ca} 2+$ mobilisation, cyclooxygenase and purinergic $\mathrm{P} 2 \mathrm{Y} 1$ and $\mathrm{P} 2 \mathrm{Y} 12$ receptor activation. Thromb Haemost 2010;103(02):398-407

105 Ward JR, Bingle L, Judge HM, et al. Agonists of toll-like receptor (TLR)2 and TLR4 are unable to modulate platelet activation by adenosine diphosphate and platelet activating factor. Thromb Haemost 2005;94(04):831-838

106 Czapiga M, Gao JL, Kirk A, Lekstrom-Himes J. Human platelets exhibit chemotaxis using functional $\mathrm{N}$-formyl peptide receptors. Exp Hematol 2005;33(01):73-84

107 Lourbakos A, Yuan YP, Jenkins AL, et al. Activation of proteaseactivated receptors by gingipains from Porphyromonas gingivalis leads to platelet aggregation: a new trait in microbial pathogenicity. Blood 2001;97(12):3790-3797

108 Pham K, Feik D, Hammond BF, Rams TE, Whitaker EJ. Aggregation of human platelets by gingipain-R from Porphyromonas gingivalis cells and membrane vesicles. Platelets 2002;13(01):21-30

109 Bhakdi S, Muhly M, Mannhardt U, et al. Staphylococcal alpha toxin promotes blood coagulation via attack on human platelets. J Exp Med 1988;168(02):527-542

110 Arvand M, Bhakdi S, Dahlbäck B, Preissner KT. Staphylococcus aureus alpha-toxin attack on human platelets promotes assembly of the prothrombinase complex. J Biol Chem 1990;265(24): 14377-14381

$111 \mathrm{Hu} \mathrm{H}$, Armstrong PCJ, Khalil E, et al. GPVI and GPIb $\alpha$ mediate staphylococcal superantigen-like protein 5 (SSL5) induced platelet activation and direct toward glycans as potential inhibitors. PLoS One 2011;6(04):e19190

112 de Haas CJC, Weeterings C, Vughs MM, de Groot PG, Van Strijp JA, Lisman T. Staphylococcal superantigen-like 5 activates platelets and supports platelet adhesion under flow conditions, which involves glycoprotein Ib $\alpha$ and $\alpha$ IIb $\beta 3$. J Thromb Haemost 2009; 7(11):1867-1874

113 Niemann S, Bertling A, Brodde MF, et al. Panton-Valentine leukocidin associated with $\mathrm{S}$. aureus osteomyelitis activates platelets via neutrophil secretion products. Sci Rep 2018;8(01):2185

114 Bertling A, Niemann S, Hussain M, et al. Staphylococcal extracellular adherence protein induces platelet activation by stimulation of thiol isomerases. Arterioscler Thromb Vasc Biol 2012;32 (08):1979-1990

115 Palma M, Shannon O, Quezada HC, Berg A, Flock JI. Extracellular fibrinogen-binding protein, Efb, from Staphylococcus aureus blocks platelet aggregation due to its binding to the alpha-chain. J Biol Chem 2001;276(34):31691-31697

116 Shannon O, Flock JI. Extracellular fibrinogen binding protein, Efb, from Staphylococcus aureus binds to platelets and inhibits platelet aggregation. Thromb Haemost 2004;91(04):779-789

117 Shannon O, Uekötter A, Flock JI. Extracellular fibrinogen binding protein, Efb, from Staphylococcus aureus as an antiplatelet agent in vivo. Thromb Haemost 2005;93(05):927-931

118 Tran U, Boyle T, Shupp JW, Hammamieh R, Jett M. Staphylococcal enterotoxin $B$ initiates protein kinase $C$ translocation and eicosanoid metabolism while inhibiting thrombin-induced aggregation in human platelets. Mol Cell Biochem 2006;288(1-2):171-178

119 Waller AK, Sage T, Kumar C, Carr T, Gibbins JM, Clarke SR. Staphylococcus aureus lipoteichoic acid inhibits platelet activation and thrombus formation via the Paf receptor. J Infect Dis 2013;208(12):2046-2057

120 Beachey EH, Chiang TM, Ofek I, Kang AH. Interaction of lipoteichoic acid of group A streptococci with human platelets. Infect Immun 1977;16(02):649-654

121 Wu BQ Zhi MJ, Liu H, Huang J, Zhou YQ, Zhang TT. Inhibitory effects of lipoteichoic acid from Staphylococcus aureus on platelet function and platelet-monocyte aggregation. Inflamm Res 2011;60(08):775-782 
122 Sheu JR, Lee CR, Lin $\mathrm{CH}$, et al. Mechanisms involved in the antiplatelet activity of Staphylococcus aureus lipoteichoic acid in human platelets. Thromb Haemost 2000;83(05):777-784

123 Chugh TD, Burns GJ, Shuhaiber HJ, Bahr GM. Adherence of Staphylococcus epidermidis to fibrin-platelet clots in vitro mediated by lipoteichoic acid. Infect Immun 1990;58(02):315-319

124 Vanassche T, Kauskot A, Verhaegen J, et al. Fibrin formation by staphylothrombin facilitates Staphylococcus aureus-induced platelet aggregation. Thromb Haemost 2012;107(06):1107-1121

125 Suehiro A, Oura Y, Ueda M, Kakishita E. Inhibitory effect of staphylokinase on platelet aggregation. Thromb Haemost 1993;70(05): 834-837

126 Kraemer BF, Campbell RA, Schwertz H, et al. Bacteria differentially induce degradation of Bcl-xL, a survival protein, by human platelets. Blood 2012;120(25):5014-5020

127 Towhid ST, Nega M, Schmidt EM, et al. Stimulation of platelet apoptosis by peptidoglycan from Staphylococcus aureus 113 . Apoptosis 2012;17(09):998-1008

128 Bhakdi S, Tranum-Jensen J. Alpha-toxin of Staphylococcus aureus. Microbiol Rev 1991;55(04):733-751

129 Guo Y-L, Liu D-Q Bian Z, Zhang C-Y, Zen K. Down-regulation of platelet surface CD47 expression in Escherichia coli 0157:H7 infection-induced thrombocytopenia. PLoS One 2009;4(09):e7131

130 Johnson MK, Boese-Marrazzo D, Pierce WA Jr. Effects of pneumolysin on human polymorphonuclear leukocytes and platelets. Infect Immun 1981;34(01):171-176

131 Bayer AS, Ramos MD, Menzies BE, Yeaman MR, Shen AJ, Cheung AL. Hyperproduction of alpha-toxin by Staphylococcus aureus results in paradoxically reduced virulence in experimental endocarditis: a host defense role for platelet microbicidal proteins. Infect Immun 1997;65(11):4652-4660

132 Bryant AE, Bayer CR, Chen RY, Guth PH, Wallace RJ, Stevens DL. Vascular dysfunction and ischemic destruction of tissue in Streptococcus pyogenes infection: the role of streptolysin 0induced platelet/neutrophil complexes. J Infect Dis 2005;192 (06):1014-1022

133 Bryant AE, Chen RY, Nagata Y, et al. Clostridial gas gangrene. II. Phospholipase C-induced activation of platelet gpIIbIIIa mediates vascular occlusion and myonecrosis in Clostridium perfringens gas gangrene. J Infect Dis 2000;182(03):808-815

134 Khan SY, Kelher MR, Heal JM, et al. Soluble CD40 ligand accumulates in stored blood components, primes neutrophils through CD40, and is a potential cofactor in the development of transfusion-related acute lung injury. Blood 2006;108(07): 2455-2462

135 Chakrabarti S, Varghese S, Vitseva O, Tanriverdi K, Freedman JE. CD40 ligand influences platelet release of reactive oxygen intermediates. Arterioscler Thromb Vasc Biol 2005;25(11):2428-2434

136 Youssefian T, Drouin A, Massé JM, Guichard J, Cramer EM. Host defense role of platelets: engulfment of HIV and Staphylococcus aureus occurs in a specific subcellular compartment and is enhanced by platelet activation. Blood 2002;99(11):4021-4029

137 Li X, Iwai T, Nakamura H, et al. An ultrastructural study of Porphyromonas gingivalis-induced platelet aggregation. Thromb Res 2008;122(06):810-819

138 White JG. Platelets are covercytes, not phagocytes: uptake of bacteria involves channels of the open canalicular system. Platelets 2005;16(02):121-131

139 Boukour S, Cramer EM. Platelet interaction with bacteria. Platelets 2005;16(3-4):215-217

140 Worth RG, Chien CD, Chien P, Reilly MP, McKenzie SE, Schreiber AD. Platelet FcgammaRIIA binds and internalizes IgG-containing complexes. Exp Hematol 2006;34(11):1490-1495

141 Antczak AJ, Vieth JA, Singh N, Worth RG. Internalization of IgGcoated targets results in activation and secretion of soluble CD40 ligand and RANTES by human platelets. Clin Vaccine Immunol 2011;18(02):210-216
142 Semple JW, Aslam R, Kim M, Speck ER, Freedman J. Plateletbound lipopolysaccharide enhances Fc receptor-mediated phagocytosis of IgG-opsonized platelets. Blood 2007;109(11): 4803-4805

143 Huang Z-Y, Chien P, Indik ZK, Schreiber AD. Human platelet FcrRIIA and phagocytes in immune-complex clearance. Mol Immunol 2011;48(04):691-696

144 Maugeri N, Rovere-Querini P, Evangelista V, et al. Neutrophils phagocytose activated platelets in vivo: a phosphatidylserine, $\mathrm{P}$ selectin, and $\beta 2$ integrin-dependent cell clearance program. Blood 2009;113(21):5254-5265

145 Manfredi AA, Rovere-Querini P, Maugeri N. Dangerous connections: neutrophils and the phagocytic clearance of activated platelets. Curr Opin Hematol 2010;17(01):3-8

146 Maugeri N, Cattaneo M, Rovere-Querini P, Manfredi AA. Platelet clearance by circulating leukocytes: a rare event or a determinant of the "immune continuum"? Platelets 2014;25(03): 224-225

147 Terada H, Baldini M, Ebbe S, Madoff MA. Interaction of influenza virus with blood platelets. Blood 1966;28(02):213-228

148 Danon D, Jerushalmy Z, De Vries A. Incorporation of influenza virus in human blood platelets in vitro. Electron microscopical observation. Virology 1959;9(04):719-722

149 Zucker-Franklin D, Seremetis S, Zheng ZY. Internalization of human immunodeficiency virus type I and other retroviruses by megakaryocytes and platelets. Blood 1990;75(10): 1920-1923

150 Beck Z, Jagodzinski LL, Eller MA, et al. Platelets and erythrocytebound platelets bind infectious HIV-1 in plasma of chronically infected patients. PLoS One 2013;8(11):e81002

151 Hamaia S, Li C, Allain J-P. The dynamics of hepatitis C virus binding to platelets and 2 mononuclear cell lines. Blood 2001;98 (08):2293-2300

152 Pugliese A, Gennero L, Cutufia M, et al. HCV infective virions can be carried by human platelets. Cell Biochem Funct 2004;22(06): 353-358

153 de Almeida AJ, Campos-de-Magalhães M, Brandão-Mello CE, et al. Detection of hepatitis $C$ virus in platelets: evaluating its relationship to antiviral therapy outcome. Hepatogastroenterology 2009;56(90):429-436

154 Forghani B, Schmidt NJ. Association of herpes simplex virus with platelets of experimentally infected mice. Arch Virol 1983;76 (03):269-274

155 Bik T, Sarov I, Livne A. Interaction between vaccinia virus and human blood platelets. Blood 1982;59(03):482-487

156 Wang S, He R, Patarapotikul J, Innis BL, Anderson R. Antibodyenhanced binding of dengue- 2 virus to human platelets. Virology 1995;213(01):254-257

157 Ghosh K, Gangodkar S, Jain P, et al. Imaging the interaction between dengue 2 virus and human blood platelets using atomic force and electron microscopy. J Electron Microsc (Tokyo) 2008; 57(03):113-118

158 Noisakran S, Gibbons RV, Songprakhon P, et al. Detection of dengue virus in platelets isolated from dengue patients. Southeast Asian J Trop Med Public Health 2009;40(02):253-262

159 Alonso AL, Cox D. Platelet interactions with viruses and parasites. Platelets 2015;26(04):317-323

160 Boilard E, Paré G, Rousseau M, et al. Influenza virus H1N1 activates platelets through FcrRIIA signaling and thrombin generation. Blood 2014;123(18):2854-2863

161 Moi ML, Lim CK, Takasaki T, Kurane I. Involvement of the Fc gamma receptor IIA cytoplasmic domain in antibody-dependent enhancement of dengue virus infection. J Gen Virol 2010;91(Pt 1):103-111

162 Rodenhuis-Zybert IA, van der Schaar HM, da Silva Voorham JM, et al. Immature dengue virus: a veiled pathogen? PLoS Pathog 2010;6(01):e1000718 
163 Negrotto S, Jaquenod de Giusti C, Rivadeneyra L, et al. Platelets interact with coxsackieviruses $B$ and have a critical role in the pathogenesis of virus-induced myocarditis. J Thromb Haemost 2015;13(02):271-282

164 Mackow ER, Gavrilovskaya IN. Cellular receptors and hantavirus pathogenesis. Curr Top Microbiol Immunol 2001;256:91-115

165 Assinger A, Kral JB, Yaiw KC, et al. Human cytomegalovirusplatelet interaction triggers toll-like receptor 2-dependent proinflammatory and proangiogenic responses. Arterioscler Thromb Vasc Biol 2014;34(04):801-809

166 Koupenova M, Vitseva O, MacKay CR, et al. Platelet-TLR7 mediates host survival and platelet count during viral infection in the absence of platelet-dependent thrombosis. Blood 2014;124(05):791-802

167 Koupenova M, Corkrey HA, Vitseva O, et al. The role of platelets in mediating a response to human influenza infection. Nat Commun 2019;10(01):1780

168 Thon JN, Peters CG, Machlus KR, et al. T granules in human platelets function in TLR9 organization and signaling. J Cell Biol 2012;198(04):561-574

169 Mesquita EC, Hottz ED, Amancio RT, et al. Persistent platelet activation and apoptosis in virologically suppressed HIVinfected individuals. Sci Rep 2018;8(01):14999

$170 \mathrm{Li}$ J, van der Wal DE, Zhu G, et al. Desialylation is a mechanism of Fc-independent platelet clearance and a therapeutic target in immune thrombocytopenia. Nat Commun 2015;6:7737

171 Sørensen AL, Rumjantseva V, Nayeb-Hashemi S, et al. Role of sialic acid for platelet life span: exposure of beta-galactose results in the rapid clearance of platelets from the circulation by asialoglycoprotein receptor-expressing liver macrophages and hepatocytes. Blood 2009;114(08):1645-1654

172 Maurice A, Marchand-Arvier M, Edert D, Le Faou A, Gondrexon G, Vigneron $C$. The virucidal effect of platelet concentrates: preliminary study and first conclusions. Platelets 2002;13(04):219-222

173 Chabert A, Hamzeh-Cognasse H, Pozzetto B, et al. Human platelets and their capacity of binding viruses: meaning and challenges? BMC Immunol 2015;16:26

174 Boukour S, Massé JM, Bénit L, Dubart-Kupperschmitt A, Cramer EM. Lentivirus degradation and DC-SIGN expression by human platelets and megakaryocytes. J Thromb Haemost 2006;4(02): 426-435

175 Jansen G, Low H, van den Brand J, van Riel D, van der Vries E. Uptake of influenza virus by platelets occurs via phagocytosis. Blood 2017;130(Suppl 1):4834

176 Jansen AJG, Low HZ, van den Brand J, van Riel D, Osterhaus A, van der Vries E. Platelets can phagocytose influenza virus which may contribute to the occurrence of thrombocytopenia during influenza infection. Blood 2016;128(22):1358

177 Kullaya VI, de Mast Q, van der Ven A, et al. Platelets modulate innate immune response against human respiratory syncytial virus in vitro. Viral Immunol 2017;30(08):576-581

178 Alonzo MT, Lacuesta TL, Dimaano EM, et al. Platelet apoptosis and apoptotic platelet clearance by macrophages in secondary dengue virus infections. J Infect Dis 2012;205(08):1321-1329

179 Stone D, Liu Y, Shayakhmetov D, Li Z-Y, Ni S, Lieber A. Adenovirusplatelet interaction in blood causes virus sequestration to the reticuloendothelial system of the liver. J Virol 2007;81(09):4866-4871

180 Trier DA, Gank KD, Kupferwasser D, et al. Platelet antistaphylococcal responses occur through $\mathrm{P} 2 \mathrm{X} 1$ and $\mathrm{P} 2 \mathrm{Y} 12$ receptor-induced activation and kinocidin release. Infect Immun 2008;76(12): 5706-5713

181 White JG. Why human platelets fail to kill bacteria. Platelets 2006;17(03):191-200

182 Coburn J, Leong JM, Erban JK. Integrin alpha IIb beta 3 mediates binding of the Lyme disease agent Borrelia burgdorferi to human platelets. Proc Natl Acad Sci U S A 1993;90(15):7059-7063

183 Kälvegren H, Majeed M, Bengtsson T. Chlamydia pneumoniae binds to platelets and triggers P-selectin expression and aggre- gation: a causal role in cardiovascular disease? Arterioscler Thromb Vasc Biol 2003;23(09):1677-1683

184 Byrne MF, Kerrigan SW, Corcoran PA, et al. Helicobacter pylori binds von Willebrand factor and interacts with GPIb to induce platelet aggregation. Gastroenterology 2003;124(07): 1846-1854

185 Naito M, Sakai E, Shi Y, et al. Porphyromonas gingivalis-induced platelet aggregation in plasma depends on Hgp44 adhesin but not Rgp proteinase. Mol Microbiol 2006;59(01):152-167

186 Pietrocola G, Schubert A, Visai L, et al. FbsA, a fibrinogen-binding protein from Streptococcus agalactiae, mediates platelet aggregation. Blood 2005;105(03):1052-1059

187 Kerrigan SW, Clarke N, Loughman A, Meade G, Foster TJ, Cox D. Molecular basis for Staphylococcus aureus-mediated platelet aggregate formation under arterial shear in vitro. Arterioscler Thromb Vasc Biol 2008;28(02):335-340

188 Loughman A, Fitzgerald JR, Brennan MP, et al. Roles for fibrinogen, immunoglobulin and complement in platelet activation promoted by Staphylococcus aureus clumping factor A. Mol Microbiol 2005;57(03):804-818

189 Miajlovic H, Loughman A, Brennan M, Cox D, Foster TJ. Both complement- and fibrinogen-dependent mechanisms contribute to platelet aggregation mediated by Staphylococcus aureus clumping factor B. Infect Immun 2007;75(07):3335-3343

190 Fitzgerald JR, Loughman A, Keane F, et al. Fibronectin-binding proteins of Staphylococcus aureus mediate activation of human platelets via fibrinogen and fibronectin bridges to integrin GPIIb/IIIa and IgG binding to the FcgammaRIIa receptor. Mol Microbiol 2006;59(01):212-230

191 O'Brien L, Kerrigan SW, Kaw G, et al. Multiple mechanisms for the activation of human platelet aggregation by Staphylococcus aureus: roles for the clumping factors ClfA and ClfB, the serine-aspartate repeat protein SdrE and protein A. Mol Microbiol 2002;44(04):1033-1044

192 Herrmann M, Suchard SJ, Boxer LA, Waldvogel FA, Lew PD. Thrombospondin binds to Staphylococcus aureus and promotes staphylococcal adherence to surfaces. Infect Immun 1991;59(01): 279-288

193 Herrmann M, Lai QJ, Albrecht RM, Mosher DF, Proctor RA Adhesion of Staphylococcus aureus to surface-bound platelets: role of fibrinogen/fibrin and platelet integrins. J Infect Dis 1993; 167(02):312-322

194 Bayer AS, Sullam PM, Ramos M, Li C, Cheung AL, Yeaman MR. Staphylococcus aureus induces platelet aggregation via a fibrinogen-dependent mechanism which is independent of principal platelet glycoprotein IIb/IIla fibrinogen-binding domains. Infect Immun 1995;63(09):3634-3641

195 Hawiger J, Steckley S, Hammond D, et al. Staphylococci-induced human platelet injury mediated by protein $\mathrm{A}$ and immunoglobulin G Fc fragment receptor. J Clin Invest 1979; 64(04):931-937

196 Nguyen T, Ghebrehiwet B, Peerschke EIB. Staphylococcus aureus protein A recognizes platelet $\mathrm{gC} 1 \mathrm{qR} / \mathrm{p} 33$ : a novel mechanism for staphylococcal interactions with platelets. Infect Immun 2000; 68(04):2061-2068

197 Zapotoczna M, Jevnikar Z, Miajlovic H, Kos J, Foster TJ. Ironregulated surface determinant B (IsdB) promotes Staphylococcus aureus adherence to and internalization by non-phagocytic human cells. Cell Microbiol 2013;15(06):1026-1041

198 Miajlovic H, Zapotoczna M, Geoghegan JA, Kerrigan SW, Speziale $P$, Foster TJ. Direct interaction of iron-regulated surface determinant IsdB of Staphylococcus aureus with the GPIIb/IIIa receptor on platelets. Microbiology 2010;156(Pt 3):920-928

199 O'Seaghdha M, van Schooten CJ, Kerrigan SW, et al. Staphylococcus aureus protein A binding to von Willebrand factor A1 domain is mediated by conserved IgG binding regions. FEBS J 2006;273 (21):4831-4841 
200 Hartleib J, Köhler N, Dickinson RB, et al. Protein A is the von Willebrand factor binding protein on Staphylococcus aureus. Blood 2000;96(06):2149-2156

201 Sjöbring U, Ringdahl U, Ruggeri ZM. Induction of platelet thrombi by bacteria and antibodies. Blood 2002;100(13):4470-4477

202 Brennan MP, Loughman A, Devocelle M, et al. Elucidating the role of Staphylococcus epidermidis serine-aspartate repeat protein $G$ in platelet activation. J Thromb Haemost 2009;7(08):1364-1372

203 Petersen HJ, Keane C, Jenkinson HF, et al. Human platelets recognize a novel surface protein, PadA, on Streptococcus gordonii through a unique interaction involving fibrinogen receptor GPIIbIIIa. Infect Immun 2010;78(01):413-422

204 Keane C, Petersen H, Reynolds K, et al. Mechanism of outside-in $\alpha$ IIb $\beta 3$-mediated activation of human platelets by the colonizing Bacterium, Streptococcus gordonii. Arterioscler Thromb Vasc Biol 2010;30(12):2408-2415

205 Takamatsu D, Bensing BA, Cheng H, et al. Binding of the Streptococcus gordonii surface glycoproteins GspB and Hsa to specific carbohydrate structures on platelet membrane glycoprotein Ibalpha. Mol Microbiol 2005;58(02):380-392

206 Kerrigan SW, Jakubovics NS, Keane C, et al. Role of Streptococcus gordonii surface proteins SspA/SspB and Hsa in platelet function. Infect Immun 2007;75(12):5740-5747

207 Mitchell J, Tristan A, Foster TJ. Characterization of the fibrinogenbinding surface protein $\mathrm{Fbl}$ of Staphylococcus lugdunensis. Microbiology 2004;150(Pt 11):3831-3841

208 Seo HS, Xiong YQ Mitchell J, Seepersaud R, Bayer AS, Sullam PM. Bacteriophage lysin mediates the binding of streptococcus mitis to human platelets through interaction with fibrinogen. PLoS Pathog 2010;6(08):e1001047

209 Mitchell J, Sullam PM. Streptococcus mitis phage-encoded adhesins mediate attachment to alpha2-8-linked sialic acid residues on platelet membrane gangliosides. Infect Immun 2009;77(08): 3485-3490

210 Tilley DO, Arman M, Smolenski A, et al. Glycoprotein Ib $\alpha$ and FcrRIla play key roles in platelet activation by the colonizing bacterium, Streptococcus oralis. J Thromb Haemost 2013;11 (05):941-950

211 Anderson R, Feldman C. Review manuscript: mechanisms of platelet activation by the pneumococcus and the role of platelets in community-acquired pneumonia. J Infect 2017;75 (06):473-485

212 Binsker U, Kohler TP, Krauel K, Kohler S, Schwertz H, Hammerschmidt S. Pneumococcal adhesins PavB and PspC are important for the interplay with human thrombospondin-1. J Biol Chem 2015; 290(23):14542-14555

213 Binsker U, Kohler TP, Krauel K, et al. Serotype 3 pneumococci sequester platelet-derived human thrombospondin-1 via the adhesin and immune evasion protein Hic. J Biol Chem 2017; 292(14):5770-5783

214 Svensson L, Baumgarten M, Mörgelin M, Shannon O. Platelet activation by Streptococcus pyogenes leads to entrapment in platelet aggregates, from which bacteria subsequently escape. Infect Immun 2014;82(10):4307-4314

215 Ford I, Douglas CW, Cox D, Rees DG, Heath J, Preston FE. The role of immunoglobulin $\mathrm{G}$ and fibrinogen in platelet aggregation by Streptococcus sanguis. Br J Haematol 1997;97(04):737-746

216 Plummer C, Wu H, Kerrigan SW, Meade G, Cox D, Ian Douglas CW. A serine-rich glycoprotein of Streptococcus sanguis mediates adhesion to platelets via GPIb. Br J Haematol 2005;129(01):101-109
217 Kerrigan SW, Douglas I, Wray A, et al. A role for glycoprotein Ib in Streptococcus sanguis-induced platelet aggregation. Blood 2002;100(02):509-516

218 Zhang Y, Bergelson JM. Adenovirus receptors. J Virol 2005;79 (19):12125-12131

219 Eggerman TL, Mondoro TH, Lozier JN, Vostal JG. Adenoviral vectors do not induce, inhibit, or potentiate human platelet aggregation. Hum Gene Ther 2002;13(01):125-128

220 Jin YY, Yu XN, Qu ZY, et al. Adenovirus type 3 induces platelet activation in vitro. Mol Med Rep 2014;9(01):370-374

221 Othman M, Labelle A, Mazzetti I, Elbatarny HS, Lillicrap D. Adenovirus-induced thrombocytopenia: the role of von Willebrand factor and P-selectin in mediating accelerated platelet clearance. Blood 2007;109(07):2832-2839

222 Simon AY, Sutherland MR, Pryzdial ELG. Dengue virus binding and replication by platelets. Blood 2015;126(03):378-385

223 Hottz ED, Oliveira MF, Nunes PC, et al. Dengue induces platelet activation, mitochondrial dysfunction and cell death through mechanisms that involve DC-SIGN and caspases. J Thromb Haemost 2013;11(05):951-962

224 Alvarez CP, Lasala F, Carrillo J, Muñiz O, Corbí AL, Delgado R. Ctype lectins DC-SIGN and L-SIGN mediate cellular entry by Ebola virus in cis and in trans. J Virol 2002;76(13):6841-6844

225 Nelsen-Salz B, Eggers HJ, Zimmermann H. Integrin alpha(v)beta3 (vitronectin receptor) is a candidate receptor for the virulent echovirus 9 strain Barty. J Gen Virol 1999;80(Pt 9):2311-2313

226 Nunez D, Charriaut-Marlangue C, Barel M, Benveniste J, Frade R. Activation of human platelets through gp140, the C3d/EBV receptor (CR2). Eur J Immunol 1987;17(04):515-520

227 Gavrilovskaya IN, Gorbunova EE, Mackow ER. Pathogenic hantaviruses direct the adherence of quiescent platelets to infected endothelial cells. J Virol 2010;84(09):4832-4839

228 Zahn A, Jennings N, Ouwehand WH, Allain JP. Hepatitis C virus interacts with human platelet glycoprotein VI. J Gen Virol 2006; 87(Pt 8):2243-2251

229 Kowalska MA, Ratajczak J, Hoxie J, et al. Megakaryocyte precursors, megakaryocytes and platelets express the HIV co-receptor CXCR4 on their surface: determination of response to stromal-derived factor- 1 by megakaryocytes and platelets. $\mathrm{Br} \mathrm{J}$ Haematol 1999;104 (02):220-229

230 Chaipan C, Soilleux EJ, Simpson P, et al. DC-SIGN and CLEC-2 mediate human immunodeficiency virus type 1 capture by platelets. J Virol 2006;80(18):8951-8960

231 Gianni T, Leoni V, Chesnokova LS, Hutt-Fletcher LM, CampadelliFiume G. $\alpha v \beta 3$-integrin is a major sensor and activator of innate immunity to herpes simplex virus-1. Proc Natl Acad Sci U S A 2012;109(48):19792-19797

232 Triantafilou K, Triantafilou M, Takada Y, Fernandez N. Human parechovirus 1 utilizes integrins alphavbeta 3 and alphavbeta 1 as receptors. J Virol 2000;74(13):5856-5862

233 Shimojima M, Ströher U, Ebihara H, Feldmann H, Kawaoka Y. Identification of cell surface molecules involved in dystroglycanindependent Lassa virus cell entry. J Virol 2012;86(04):2067-2078

234 Coulson BS, Londrigan SL, Lee DJ. Rotavirus contains integrin ligand sequences and a disintegrin-like domain that are implicated in virus entry into cells. Proc Natl Acad Sci U S A 1997;94 (10):5389-5394

235 Fleming FE, Graham KL, Takada Y, Coulson BS. Determinants of the specificity of rotavirus interactions with the alpha2beta1 integrin. J Biol Chem 2011;286(08):6165-6174 